\title{
Evidence for Early Mesoproterozoic Arc Magmatism in the Musgrave Block, Central Australia: Implications for Proterozoic Crustal Growth and Tectonic Reconstructions of Australia
}

\author{
B. P. Wade, K. M. Barovich, M. Hand, I. R. Scrimgeour, ${ }^{1}$ and D. F. Close ${ }^{1}$ \\ Continental Evolution Research Group, Geology and Geophysics, University of Adelaide, \\ Adelaide, South Australia 5005, Australia \\ (e-mail: benjamin.wade@adelaide.edu.au)
}

\begin{abstract}
A B S T R A C T
The Musgrave Block in central southern Australia separates the dominantly Paleoproterozoic North Australian Craton from the Late Archean to early Mesoproterozoic Gawler Craton in southern Australia. Geochemical and Nd isotopic data from 1.59-1.55-Ga felsic rocks in the Mann Ranges suggest that the early history of the Musgrave Block was linked to the development of subduction along the northern margin of the Gawler Craton. Characteristic geochemical patterns of these felsic rocks include negative anomalies in $\mathrm{Nb}, \mathrm{Ti}$, and $\mathrm{Y}$ and are accompanied by steep light rare earth element patterns and comparatively juvenile $\mathrm{Nd}$ isotopic compositions $\left(\varepsilon_{\mathrm{Nd}}(1550)\right.$ values from -1.2 to 0.9$)$. The geochemical and isotopic signatures of these early Mesoproterozoic felsic rocks have similarities with island arc systems involving residual Ti-bearing minerals and garnet. We propose that the 1.59-1.55-Ga arclike rocks in the Musgrave Block indicate the presence of an active margin between the North Australian Craton and the South Australian Craton, with subsequent suturing of the Australian continent during the early Mesoproterozoic. The existence of arclike magmatism in the Musgrave Block during the early Mesoproterozoic suggests a period of major crustal growth in the Australian Proterozoic that has important implications for current Proterozoic reconstructions of Australia and Australia's fit within the supercontinent Rodinia.
\end{abstract}

\section{Introduction}

Crustal growth models of Late Archean to early Mesoproterozoic Australia (e.g., Rutland 1973; Gee 1979; Etheridge et al. 1987; Wyborn et al. 1988; Oliver et al. 1991) have been dominated by the assumption that the Australian lithosphere was a single stabilized mass by the Late Archean. In these models, crustal formation and growth proceeded by processes such as vertical accretion involving underplating and extensional tectonism driven by mantle plumes and delamination. This view of a contiguous Late Archean to Proterozoic Australia envisages all tectonic and magmatic activity to be intracratonic, independent of plate boundary elements involving driving forces such as subduction zones, with little or no new crustal growth.

In contrast to these models for Proterozoic Australia, rapid crustal production by the lateral ac-

Manuscript received April 1, 2005; accepted August 23, 2005.

${ }^{1}$ Northern Territory Geological Survey, G.P.O. Box 3000, Darwin, Northern Territory 0801, Australia. cretion of magmatic arc terranes has been viewed as the primary continent-forming process in many of the ca. 2.0-1.8-Ga Proterozoic orogenic belts in the Northern Hemisphere (e.g., Hoffman 1980, 1988; Lewry 1981; Condie 1982; Park 1985; Patchett and Arndt 1986; Dickin and McNutt 1990; Snyder et al. 1996; Torsvik et al. 1996; Patchett and Chase 2002; Steltenpohl et al. 2003). Recent geochemical and isotopic studies within Australian terrains such as the Arunta Region and the Capricorn Orogen have recognized, albeit in a somewhat cryptic way, accreted fragments along convergent plate margins (e.g., Zhao 1994; Zhao and McCulloch 1995; Scrimgeour et al. 1999; Cawood and Tyler 2004; Occhipinti et al. 2004). These data sets have been used by a number of workers to propose that the evolution of Proterozoic Australia involved important accretionary and collisional events (e.g., Myers et al. 1996; Scott et al. 2000; Betts et al. 2002; Giles et al. 2002, 2004; Tyler 2005). Identification of Paleoproterozoic arc magma-

[The Journal of Geology, 2006, volume 114, p. 43-63] @ 2006 by The University of Chicago. All rights reserved. 0022-1376/2006/11401-0003\$15.00 
tism in Australia is restricted to a few cratonic margins of the Archean to Paleoproterozoic terrains, such as the North Australian Craton (NAC), including the eastern Isan margin, the southern margin of the Arunta Region, and the Halls Creek Orogen (fig. 1; e.g., Foden et al. 1988; Zhao 1994; Zhao and McCulloch 1995; McDonald et al. 1997; Sheppard et al. 1999; Close et al. 2004), and the West Australian Craton (WAC), including the Capricorn Orogen (fig. 1; e.g., Cawood and Tyler 2004; Occhipinti et al. 2004). Mafic and felsic magmatic rocks with subduction-related geochemical affinities from these regions have been viewed as a result of Paleoproterozoic arc magmatism (e.g., Foden et al. 1988; Zhao 1992; Zhao and McCulloch 1995; Sheppard et al. 1999, 2004; Cawood and Tyler 2004;
Occhipinti et al. 2004). Felsic orthogneiss from basement to the Isan region have also been suggested to have magmatic arc affinities (McDonald et al. 1997).

This study focuses on the Musgrave Block, which is located in central Australia between the NAC and the South Australian Craton (SAC; fig. 1). Extensive reworking during the Grenvillian Musgrave Orogeny (ca. 1.3-1.1 Ga) and NeoproterozoicCambrian Petermann Orogeny (ca. 600-530 Ma) has resulted in a complexly deformed terrain, with existing models suggesting that the Albany-Fraser Orogeny coincident with the Musgrave Orogeny reflects the collision of the NAC with the SAC during the assembly of Rodinia at $\sim 1.30-1.10$ Ga (fig. 1; e.g., Pidgeon 1990; Black et al. 1992; Myers 1993;

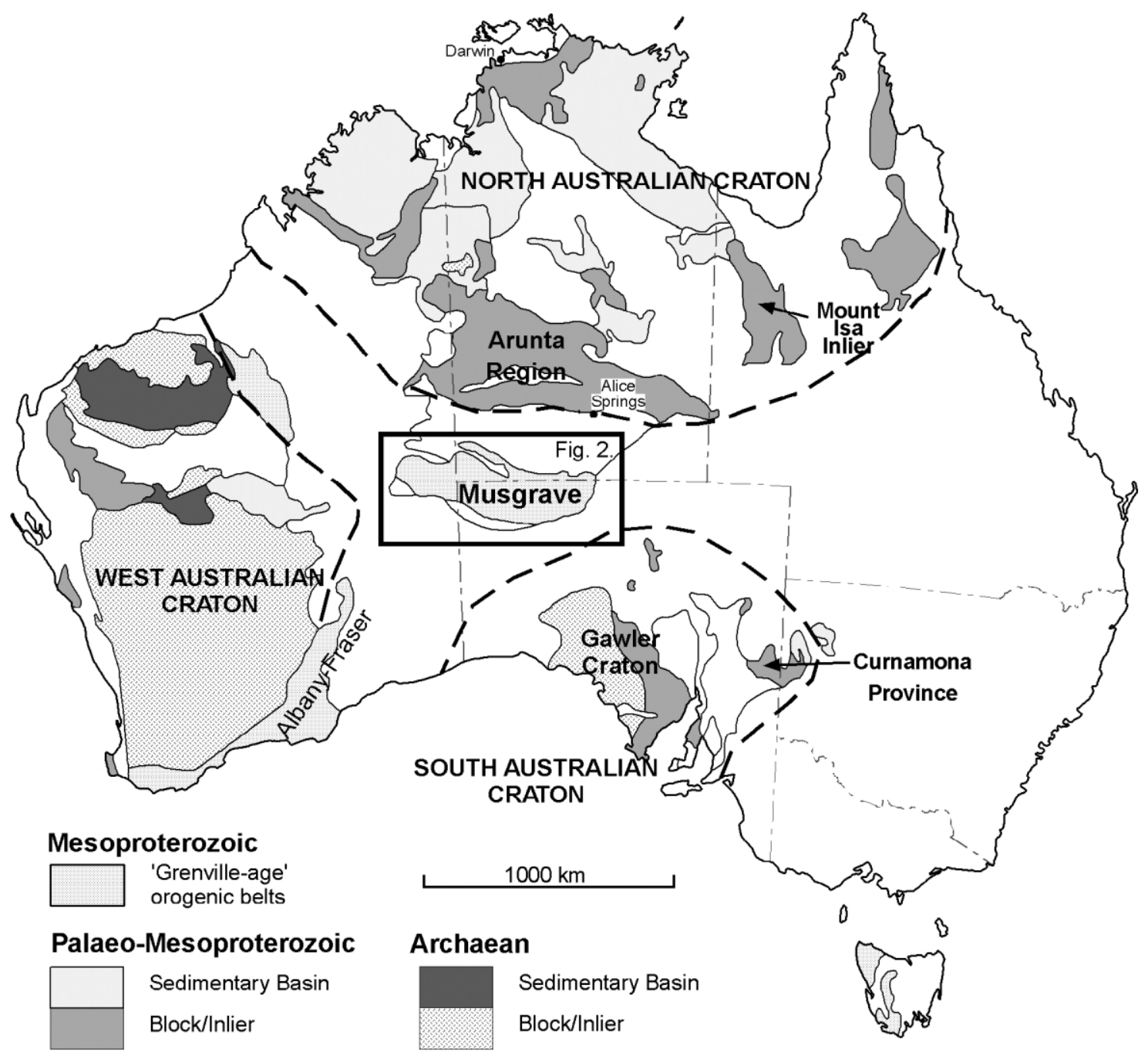

Figure 1. Map of Australia displaying the locations of Archean cratons and Paleoproterozoic-Mesoproterozoic terrains. The rectangle designates the area displayed in figure 2. 
Myers et al. 1996; Clark et al. 1999, 2000; White et al. 1999). Alternatively, Şener et al. (2005) have proposed suturing of the NAC with the SAC much earlier, at ca. $1.73 \mathrm{Ga}$, with similar suturing of the continents between 1.8 and $1.5 \mathrm{Ga}$ proposed by Giles et al. (2004).

Geochronological studies on felsic rocks situated in the northern and western Musgrave Block show that they are early Mesoproterozoic in age, and to date they represent the oldest recognized crustal material within the Musgrave Block (Gray 1978; Maboko et al. 1991; Sun and Sheraton 1992; Camacho and Fanning 1995; Scrimgeour et al. 1999). The rocks outcrop discontinuously along the length of the northern Musgrave Block (fig. 2; Edgoose et al. 1993, 2004; Scrimgeour et al. 1999).
Lithological and stratigraphic correlations indicate that these felsic rocks may extend into the southern Musgrave Block; however, the absence of geochronological constraints has hindered their identification.

Recent geochemical studies in the western and northern Musgrave Block have hinted at major crust-forming and magmatic episodes at ca. 1.59$1.55 \mathrm{Ga}$, of which the felsic rocks analyzed in this study are a part (Glikson et al. 1996; Scrimgeour et al. 1999). These workers tentatively suggest that the Musgrave Block contains a history of crustal formation that may involve plate margin processes.

Late Proterozoic (ca. 1.08 Ga) mafic dike swarms in both the Arunta Region and the Musgrave Block also support episodes of large-scale crustal growth

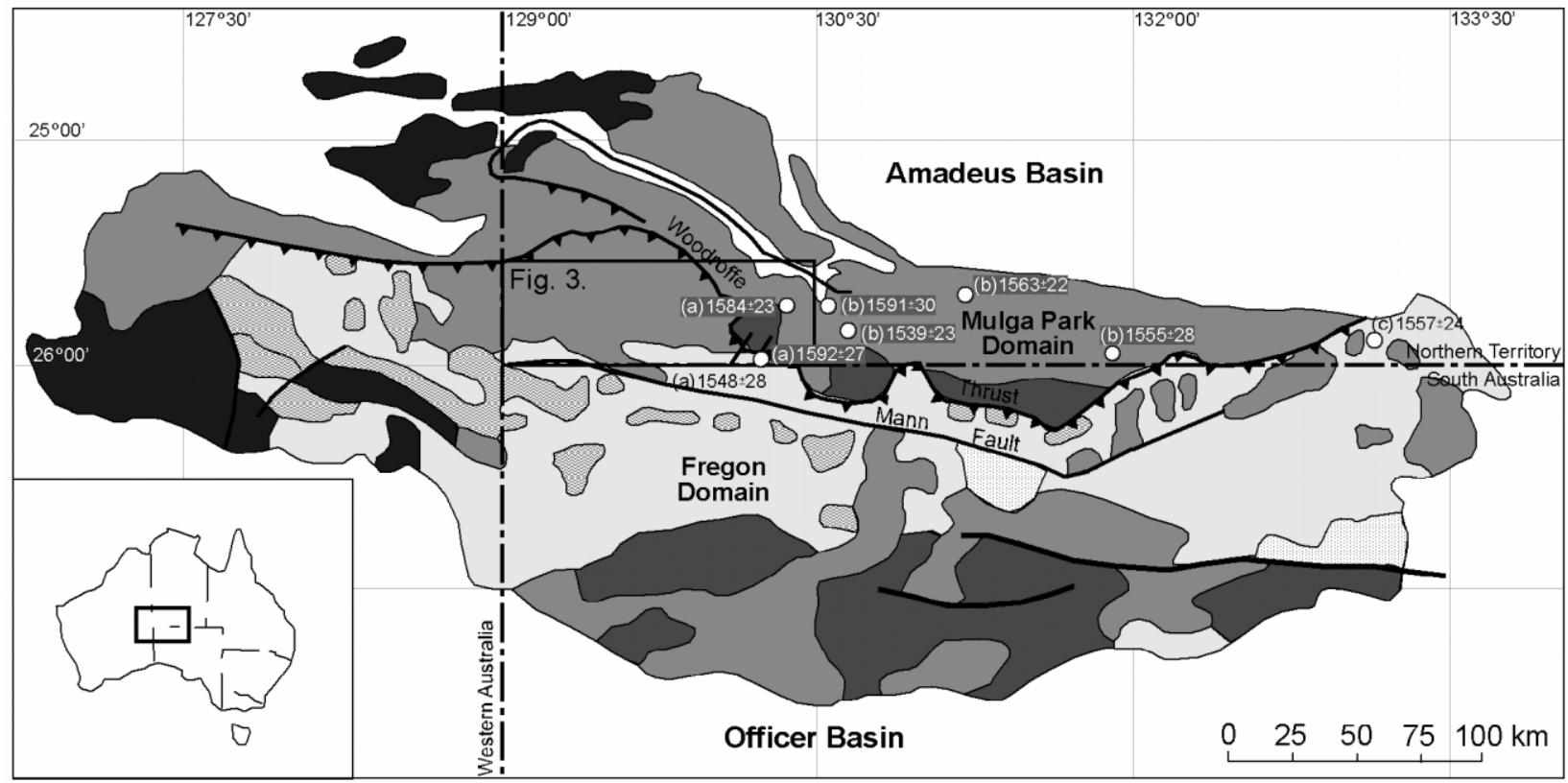

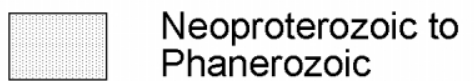

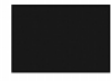

ca. $1.09-1.05 \mathrm{Ga}$ granites/sediments

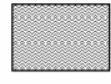

Giles Complex

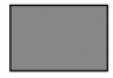

Dominantly $1200-1050$ Ma granite

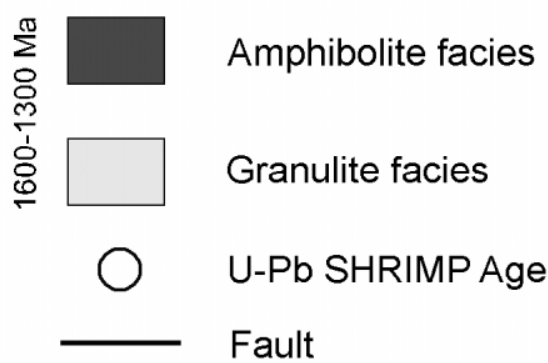

$\stackrel{\sim}{\sim}$ Thrust

Figure 2. Simplified geological map displaying the Musgrave Block and locations of samples dated by previous workers using SHRIMP (a, Scrimgeour et al. [1999]; b, Young et al. [2002]; c, Camacho and Fanning [1995]). The rectangle shows the approximate location of figure 3. 
in the early Mesoproterozoic (Zhao and McCulloch 1993). The $\sim 1.08-\mathrm{Ga}$ high-Mg, low-Ti tholeiites of the Stuart Dike Swarm and the Alcurra Dolerite (formerly the Kulgera Dikes) of the Arunta Region and the Musgrave Block, respectively, have isotopic and geochemical signatures that are interpreted as recording modification of the subcontinental lithospheric mantle by subduction processes during the Proterozoic (Zhao and McCulloch 1993; Zhao 1994).

In this article, we present geochemical and $\mathrm{Nd}$ isotopic data from felsic rocks along the northern Musgrave Block. The combination of the Sm-Nd isotopic system with rare earth elements (REEs) and geochemistry has proved to be a powerful tool in the investigation of crustal growth mechanisms throughout the world (e.g., Johannes et al. 1995; Kepezhinskas et al. 1997; Whalen et al. 1999; Hussain et al. 2004). In many orogenic belts, subsequent tectonic processes have obscured the geochemical and geophysical characteristics of the accreted terrane. Robust geochemical tracers and $\mathrm{Sm}-\mathrm{Nd}$ isotopes can see through accreting tectonic events to determine the evolution of the terrane (e.g., Dunphy and Ludden 1998; Whalen et al. 1999; Gorton and Schandl 2000; Roberts et al. 2000; Blein et al. 2003; Hussain et al. 2004). In this study, we present evidence for a magmatic arc origin for ca. 1.59-1.55-Ga felsic rocks in the Musgrave Block. Comparisons are made with recognized magmatic arc rocks from other Proterozoic terrains. We provide a tectonic interpretation for the formation of the Musgrave Block involving new crustal growth and accretionary processes.

The Musgrave Block represents a critical link in understanding the process and timing of the suturing of the NAC with the SAC as part of the larger Mawson Continent (e.g., Fanning et al. 1996), as it lies on the interface between the two aforementioned crustal elements. Understanding the tectonic setting involved in the formation of the protolith felsic rocks of the Musgrave Block has important implications for any future work involving Proterozoic reconstructions of Australia.

\section{Geological Framework}

The Musgrave Block is an early Mesoproterozoic to Neoproterozoic orogenic belt located in central Australia, straddling the South Australia and Northern Territory border and extending into Western Australia (fig. 1). Lithologies consist of highgrade rocks (amphibolite to granulite facies) with volcanic and, less commonly, sedimentary precursors (e.g., Conor 1987; Scrimgeour et al. 1999) that are intruded by numerous younger granitoids and mafic and felsic dikes (fig. 2).

The oldest recognized components of the Musgrave Block are granulite to amphibolite facies felsic rocks, some of which have been dated in the northern Musgrave Block (figs. 2, 3). SHRIMP U$\mathrm{Pb}$ analyses on zircon cores from these felsic rocks give an age spread of $\sim 1.59-1.55 \mathrm{Ga}$, which is interpreted as representing the crystallization ages of the intrusive igneous precursor (fig. 2; Edgoose et al. 1993, 2004; Camacho and Fanning 1995; Scrimgeour et al. 1999).

The ca. 1.59-1.55-Ga felsic rocks from the Mann Ranges that are the focus of this study are migmatitic and typically contain orthopyroxene, clinopyroxene, and biotite, with garnet less common. Regions of homogeneous felsic gneiss are likely to have an igneous intrusive precursor (e.g., Scrimgeour et al. 1999). Elsewhere, felsic gneiss is interlayered with mafic granulite and, less commonly, pelitic gneiss, suggesting a possible bimodal volcanic precursor or intrusion of mafic sills into a supracrustal sequence (Scrimgeour et al. 1999).

Metamorphic zircon growth in these rocks gives ages in the range ca. 1.20-1.16 Ma (Maboko et al. 1991; Camacho and Fanning 1995; Camacho 1997; Scrimgeour et al. 1999), reflecting the Grenvillianaged Musgrave Orogeny. Evidence for a more complex metamorphic history, with an earlier phase of metamorphism in the Musgrave Ranges at 1550 $\mathrm{Ma}$, has been proposed by Camacho (1997). In the western regions of the Musgrave Block, additional granulite facies metamorphic events at ca. 1300 and ca. 1080 Ma have been proposed (Clarke et al. 1995; White et al. 1999).

During and after the Musgrave Orogeny, extensive granitic magmatism occurred in the interval of ca. 1.20-1.14 Ga, affecting a large portion of the Musgrave Block (Edgoose et al. 1993, 2004; Camacho and Fanning 1995; Scrimgeour et al. 1999; Young et al. 2002). This was followed by the Warakurna igneous event at ca. 1.08-1.05 Ga (Wingate et al. 2004), resulting in the emplacement of the layered mafic intrusive bodies of the Giles Complex (fig. 2), the Alcurra Dolerite, and the bimodal volcanics and associated rift sediments of the Tjauwata Group and Bentley Supergroup, representing part of the Warakurna Igneous Province (Edgoose et al. 1993; Glikson et al. 1995, 1996; Sun et al. 1996; Scrimgeour et al. 1999; Wingate et al. 2004). The Amata Dike Swarm and equivalents represent plume-related mafic intrusions at $\sim 0.80 \mathrm{Ga}$, possibly related to initiation of the Centralian Superbasin, which covered much of central and southern late Proterozoic Australia (fig. 2; Maboko 1988; 


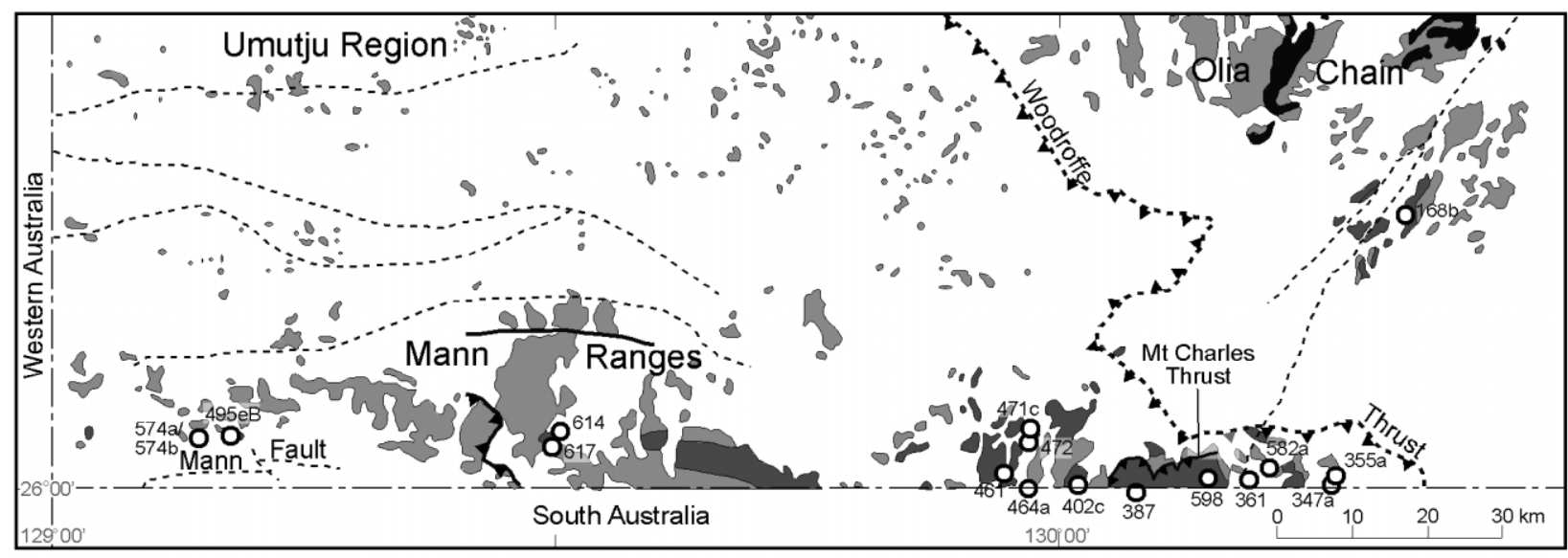

Amadeus Basin

Dean Quartzite

\section{Musgrave Block}

1200-1050 Ma Granite

ca.1.59-1.55 Ga felsic gneisses
Fault

Fault; concealed

$\sim$ Fault; thrust

Fault; thrust (concealed)

Sample Location/

Sample No.

Figure 3. Outcrop map showing location of samples used in this study.

Zhao and McCulloch 1993; Zhao et al. 1994; Walter et al. 1995).

Subsequent to the intrusion of these mafic dikes was a major intracratonic event, the Petermann Orogeny (e.g., Camacho et al. 1997; Scrimgeour and Close 1999; Camacho and McDougall 2000). This Neoproterozoic-Cambrian event (ca. 0.60-0.53 Ga) was associated with the formation of widespread mylonitic fabrics throughout the Mann Ranges (e.g., Camacho et al. 1997; Scrimgeour et al. 1999).

\section{Analytical Procedure}

Eighteen whole-rock samples of felsic lithology have been analyzed in this study for major and trace elements and Sm-Nd isotopes. Sample locations, chemistry, and $\mathrm{Nd}$ isotope data are shown in tables 1,2 , and 3 .

Whole-rock samples of felsic gneiss were crushed and powdered in a tungsten carbide mill. For analysis of major elements, a 0.1-g subsample of the analytical pulp was fused with lithium metaborate and dissolved in nitric acid solution to give a "total solution" ready for ICPMS (inductively coupled plasma mass spectrometer) analysis. Analysis of trace elements and REEs was achieved by digestion of up to $0.5 \mathrm{~g}$ of the analytical pulp in a HF/multiacid solution and presented to an ICPMS for the quantification of the elements of interest. All dissolution and element analyses were carried out at the Amdel Laboratories in Adelaide.

Whole-rock samples analyzed for Sm-Nd isotopic composition were evaporated in $\mathrm{HF} / \mathrm{HNO}_{3}$ overnight, digested in hot $\mathrm{HF} / \mathrm{HNO}_{3}$ in sealed Teflon bombs for $5 \mathrm{~d}$, and evaporated to dryness in $\mathrm{HF} /$ $\mathrm{HNO}_{3}$. Samples were subsequently evaporated in $6 \mathrm{M} \mathrm{HCl}$ and then bombed with $6 \mathrm{M} \mathrm{HCl}$ overnight. $\mathrm{Nd}$ and $\mathrm{Sm}$ concentrations were calculated by isotope dilution, with $\mathrm{Nd}$ isotope ratios measured by thermal ionization mass spectrometry on a Finnigan MAT 262 mass spectrometer and Sm isotope ratios measured on a Finnigan MAT 261 mass spectrometer. The ${ }^{143} \mathrm{Nd} /{ }^{144} \mathrm{Nd}$ ratio was normalized to ${ }^{146} \mathrm{Nd} /{ }^{144} \mathrm{Nd}=0.721903 . \mathrm{Nd}$ blanks carried out during the course of the analyses ranged from 101 to $108 \mathrm{pg}$. The ${ }^{143} \mathrm{Nd} /{ }^{144} \mathrm{Nd}$ ratio of the in-house 
Table 1. Chemical Data for Yb-Enriched Musgrave Felsic Rocks

\begin{tabular}{|c|c|c|c|c|c|c|c|c|c|c|c|}
\hline $\begin{array}{l}\text { Sample } \\
\text { Easting } \\
\text { Northing }\end{array}$ & $\begin{array}{c}95 / 461 \\
52594550 \\
7125725\end{array}$ & $\begin{array}{c}96 / 614 \\
52551150 \\
7130210\end{array}$ & $\begin{array}{c}95 / 168 b \\
52634960 \\
7154000\end{array}$ & $\begin{array}{c}96 / 617 \\
52549800 \\
7129000\end{array}$ & $\begin{array}{c}95 / 464 a \\
52597025 \\
7124000\end{array}$ & $\begin{array}{c}95 / 472 \\
52597075 \\
7129300\end{array}$ & $\begin{array}{c}95 / 471 C \\
52597260 \\
7130780\end{array}$ & $\begin{array}{c}95 / 361 \\
52618820 \\
7124980\end{array}$ & $\begin{array}{c}95 / 598 \\
52614780 \\
7125200\end{array}$ & $\begin{array}{c}95 / 402 c \\
52601900 \\
7124560\end{array}$ & $\begin{array}{c}96 / 582 a \\
52620900 \\
7126000\end{array}$ \\
\hline \multicolumn{12}{|c|}{ Major elements (wt\%): } \\
\hline $\mathrm{SiO}_{2}$ & 67.30 & 69.80 & 67.40 & 69.60 & 69.70 & 70.70 & 69.40 & 71.70 & 66.80 & 67.70 & 69.20 \\
\hline $\mathrm{Al}_{2} \mathrm{O}_{3}$ & 13.60 & 13.50 & 14.00 & 13.60 & 14.10 & 13.30 & 13.40 & 13.80 & 14.20 & 14.90 & 14.40 \\
\hline $\mathrm{Fe}_{2} \mathrm{O}_{3}$ & 5.67 & 4.73 & 4.88 & 3.99 & 3.84 & 3.41 & 3.98 & 3.30 & 6.27 & 3.88 & 3.28 \\
\hline $\mathrm{MnO}$ & .13 & .11 & .14 & .10 & .11 & .11 & .10 & .08 & .17 & .11 & .09 \\
\hline $\mathrm{MgO}$ & 1.19 & .97 & 1.28 & .76 & .73 & .63 & .83 & .64 & 1.79 & .97 & .84 \\
\hline $\mathrm{CaO}$ & 3.77 & 3.24 & 3.24 & 2.28 & 3.81 & 2.46 & 2.84 & 2.44 & 3.97 & 3.54 & 2.70 \\
\hline $\mathrm{Na}_{2} \mathrm{O}$ & 3.18 & 2.88 & 2.95 & 2.95 & 3.57 & 3.41 & 2.92 & 2.89 & 3.08 & 3.40 & 3.23 \\
\hline $\mathrm{K}_{2} \mathrm{O}$ & 3.37 & 4.08 & 4.10 & 4.65 & 3.22 & 4.38 & 4.42 & 4.83 & 2.44 & 3.62 & 4.92 \\
\hline $\mathrm{TiO}_{2}$ & .83 & .69 & .73 & .66 & .69 & .56 & .63 & .55 & .88 & .58 & .52 \\
\hline $\mathrm{P}_{2} \mathrm{O}_{5}$ & .19 & .15 & .17 & .11 & .14 & .12 & .13 & .10 & .18 & .11 & .10 \\
\hline LOI & .11 & .26 & .60 & .55 & .27 & .20 & .44 & .19 & .11 & .52 & .41 \\
\hline Total & 99.34 & 100.41 & 99.49 & 99.25 & 100.18 & 99.28 & 99.09 & 100.52 & 99.89 & 99.33 & 99.69 \\
\hline \multicolumn{12}{|c|}{ Trace and rare earth elements (REEs; ppm): } \\
\hline $\mathrm{Ga}$ & 20.0 & 18.5 & 19.0 & 17.5 & 22.5 & 17.0 & 19.0 & 17.0 & 21.5 & 21.5 & 20.0 \\
\hline $\mathrm{Cr}$ & 30.0 & 10.0 & 10.0 & 20.0 & 20.0 & 10.0 & 10.0 & 20.0 & 20.0 & 10.0 & 10.0 \\
\hline $\mathrm{Ni}$ & 8.0 & 6.0 & 9.0 & 5.0 & 6.0 & 4.0 & 5.0 & 5.0 & 15.0 & 7.0 & 5.0 \\
\hline Sc & 14.0 & 12.0 & 14.0 & 6.0 & 10.0 & 10.0 & 10.0 & 8.0 & 16.0 & 10.0 & 8.0 \\
\hline $\mathrm{V}$ & 60.0 & 50.0 & 60.0 & 40.0 & 60.0 & 30.0 & 40.0 & 30.0 & 90.0 & 50.0 & 40.0 \\
\hline $\mathrm{Y}$ & 54.0 & 40.5 & 46.5 & 37.0 & 44.5 & 44.5 & 45.0 & 29.5 & 36.0 & 27.5 & 40.0 \\
\hline $\mathrm{Rb}$ & 94.0 & 130.0 & 165.0 & 135.0 & 110.0 & 140.0 & 155.0 & 145.0 & 70.0 & 100.0 & 145.0 \\
\hline $\mathrm{Ba}$ & 850.0 & 950.0 & 900.0 & 1050.0 & 700.0 & 1000.0 & 950.0 & 1000.0 & 550.0 & 1050.0 & 1350.0 \\
\hline Th & 2.4 & 6.0 & 19.0 & 5.0 & 22.5 & 14.5 & 21.5 & 4.9 & 1.8 & 5.5 & 13.0 \\
\hline $\mathrm{U}$ & .2 & .5 & 2.5 & .6 & 1.3 & 1.6 & 1.0 & .3 & .2 & .4 & .4 \\
\hline $\mathrm{Ta}$ & 1.0 & 1.0 & 2.0 & 3.0 & 3.0 & 1.0 & 2.0 & 1.0 & 1.0 & 1.0 & 1.0 \\
\hline $\mathrm{Nb}$ & 15.5 & 13.0 & 18.0 & 19.0 & 21.0 & 15.0 & 17.0 & 13.0 & 14.5 & 11.5 & 13.0 \\
\hline $\mathrm{Pb}$ & 28.5 & 30.0 & 40.0 & 36.5 & 31.5 & 29.0 & 34.0 & 32.0 & 24.5 & 33.0 & 33.0 \\
\hline Hf & 8.0 & 7.0 & 7.0 & 8.0 & 9.0 & 8.0 & 8.0 & 9.0 & 8.0 & 6.0 & 9.0 \\
\hline $\mathrm{Sr}$ & 150.0 & 140.0 & 180.0 & 150.0 & 150.0 & 135.0 & 145.0 & 135.0 & 160.0 & 230.0 & 310.0 \\
\hline $\mathrm{Ti}$ & 4941.8 & 4103.2 & 4372.7 & 3923.5 & 4133.1 & 3324.5 & 3773.7 & 3294.5 & 5271.2 & 3474.2 & 3114.8 \\
\hline $\mathrm{Zr}$ & 280.0 & 230.0 & 250.0 & 260.0 & 250.0 & 260.0 & 260.0 & 280.0 & 280.0 & 220.0 & 310.0 \\
\hline $\mathrm{La}$ & 48.0 & 42.0 & 46.5 & 38.5 & 54.0 & 52.0 & 58.0 & 40.0 & 52.0 & 38.0 & 64.0 \\
\hline $\mathrm{Ce}$ & 100.0 & 84.0 & 96.0 & 86.0 & 105.0 & 100.0 & 110.0 & 76.0 & 105.0 & 66.0 & 120.0 \\
\hline $\operatorname{Pr}$ & 12.5 & 10.0 & 10.5 & 8.5 & 12.0 & 12.0 & 13.0 & 8.5 & 12.5 & 8.0 & 14.0 \\
\hline $\mathrm{Nd}$ & 46.5 & 35.5 & 39.0 & 31.5 & 41.0 & 42.0 & 44.0 & 31.5 & 44.0 & 28.5 & 50.0 \\
\hline $\mathrm{Sm}$ & 10.5 & 7.5 & 8.5 & 7.0 & 8.5 & 8.5 & 8.5 & 6.0 & 9.0 & 5.5 & 9.5 \\
\hline $\mathrm{Eu}$ & 2.0 & 1.9 & 1.9 & 2.0 & 1.7 & 1.8 & 1.9 & 1.7 & 1.6 & 1.9 & 2.2 \\
\hline $\mathrm{Gd}$ & 9.0 & 6.5 & 7.0 & 6.5 & 7.0 & 7.5 & 7.0 & 5.0 & 7.0 & 5.0 & 8.0 \\
\hline $\mathrm{Tb}$ & 1.7 & 1.3 & 1.3 & 1.2 & 1.3 & 1.3 & 1.4 & 1.0 & 1.3 & .9 & 1.3 \\
\hline Dy & 10.5 & 7.5 & 8.0 & 7.0 & 8.0 & 8.0 & 8.5 & 5.5 & 7.5 & 5.5 & 7.5 \\
\hline Ho & 2.0 & 1.5 & 1.8 & 1.5 & 1.7 & 1.7 & 1.7 & 1.2 & 1.5 & 1.0 & 1.5 \\
\hline Er & 6.0 & 4.7 & 5.0 & 4.2 & 5.0 & 5.0 & 5.5 & 3.5 & 4.1 & 3.0 & 4.6 \\
\hline $\mathrm{Tm}$ & .9 & .7 & .8 & .6 & .8 & .8 & .8 & .5 & .6 & .4 & .7 \\
\hline $\mathrm{Yb}$ & 5.5 & 4.7 & 5.0 & 3.9 & 5.0 & 4.8 & 5.0 & 3.3 & 3.7 & 2.7 & 4.2 \\
\hline $\mathrm{Lu}$ & .8 & .7 & .8 & .6 & .8 & .8 & .8 & .5 & .5 & .4 & .6 \\
\hline Total REEs & 255.81 & 208.45 & 231.85 & 198.96 & 251.62 & 246.12 & 266.00 & 184.10 & 250.22 & 166.78 & 288.03 \\
\hline ASI & .86 & .90 & .92 & .97 & .87 & .90 & .91 & .96 & .95 & .93 & .93 \\
\hline$(\mathrm{La} / \mathrm{Yb})_{\mathrm{N}}$ & 5.90 & 6.04 & 6.28 & 6.67 & 7.30 & 7.32 & 7.84 & 8.19 & 9.50 & 9.51 & 10.30 \\
\hline$(\mathrm{La} / \mathrm{Sm})_{\mathrm{N}}$ & 2.88 & 3.52 & 3.44 & 3.46 & 4.00 & 3.85 & 4.29 & 4.20 & 3.64 & 4.35 & 4.24 \\
\hline$(\mathrm{Gd} / \mathrm{Yb})_{\mathrm{N}}$ & 1.33 & 1.12 & 1.13 & 1.35 & 1.13 & 1.27 & 1.13 & 1.23 & 1.53 & 1.50 & 1.54 \\
\hline$\left(\mathrm{Eu} / \mathrm{Eu}^{*}\right)_{\mathrm{N}}$ & .63 & .83 & .73 & .91 & .65 & .69 & .75 & .92 & .62 & 1.11 & .77 \\
\hline
\end{tabular}

Note. $\quad$ LOI $=$ loss on ignition. ASI = aluminum saturation index.

standard (Johnson Matthey) at the Adelaide University laboratory during the course of the analysis was $0.511594 \pm 0.000006$ ( $1 \sigma$, five analyses). Running average for La Jolla over the year was $0.511838 \pm 0.000008$ ( $1 \sigma$, six analyses $)$.

\section{Geochemistry of the Felsic Gneisses}

Major Elements. Major-element analyses are summarized in tables 1 and $2 . \mathrm{SiO}_{2}$ values for the samples range from $\sim 66 \%$ to $76 \%$ (tables 1,2 ). Samples have been split into two groups according to $(\mathrm{La} / \mathrm{Yb})_{\mathrm{N}}$ values, where the $\mathrm{Yb}$-enriched group consists of 11 samples with $(\mathrm{La} / \mathrm{Yb})_{\mathrm{N}}<12$ and the $\mathrm{Yb}$ - depleted group consists of seven samples with $(\mathrm{La} / \mathrm{Yb})_{\mathrm{N}}>12$ (tables 1, 2).

$\mathrm{Yb}$-enriched samples have moderate silica (66.8$71.7 \mathrm{wt} \%)$ and $\mathrm{K}_{2} \mathrm{O}(2.4-4.9 \mathrm{wt} \%)$, with high $\mathrm{Al}_{2} \mathrm{O}_{3}$ (13.3-14.9 wt\%) and $\mathrm{Na}_{2} \mathrm{O}(2.9-3.6 \mathrm{wt} \%)$. $\mathrm{Yb}-$ depleted samples generally have high silica (66.0$76.0 \mathrm{wt} \%)$ and $\mathrm{K}_{2} \mathrm{O}(4.1-5.7 \mathrm{wt} \%)$, with moderate $\mathrm{Al}_{2} \mathrm{O}_{3}(11.9-16.7 \mathrm{wt} \%)$ and moderate $\mathrm{Na}_{2} \mathrm{O}$ (1.6-3.3 $\mathrm{wt} \%$; table 1). Major-element oxides generally show linear trends on Harker diagrams, with an increase in $\mathrm{K}_{2} \mathrm{O}$ and a systematic decrease of $\mathrm{Al}_{2} \mathrm{O}_{3}$, $\mathrm{CaO}$, and $\mathrm{TiO}_{2}$ with increasing silica content (fig. 4). The majority of samples are metaluminous, with an aluminum saturation index (ASI) of $<1$, the 
Table 2. Chemical Data for Yb-Depleted Musgrave Felsic Rocks and Average ADR Suites

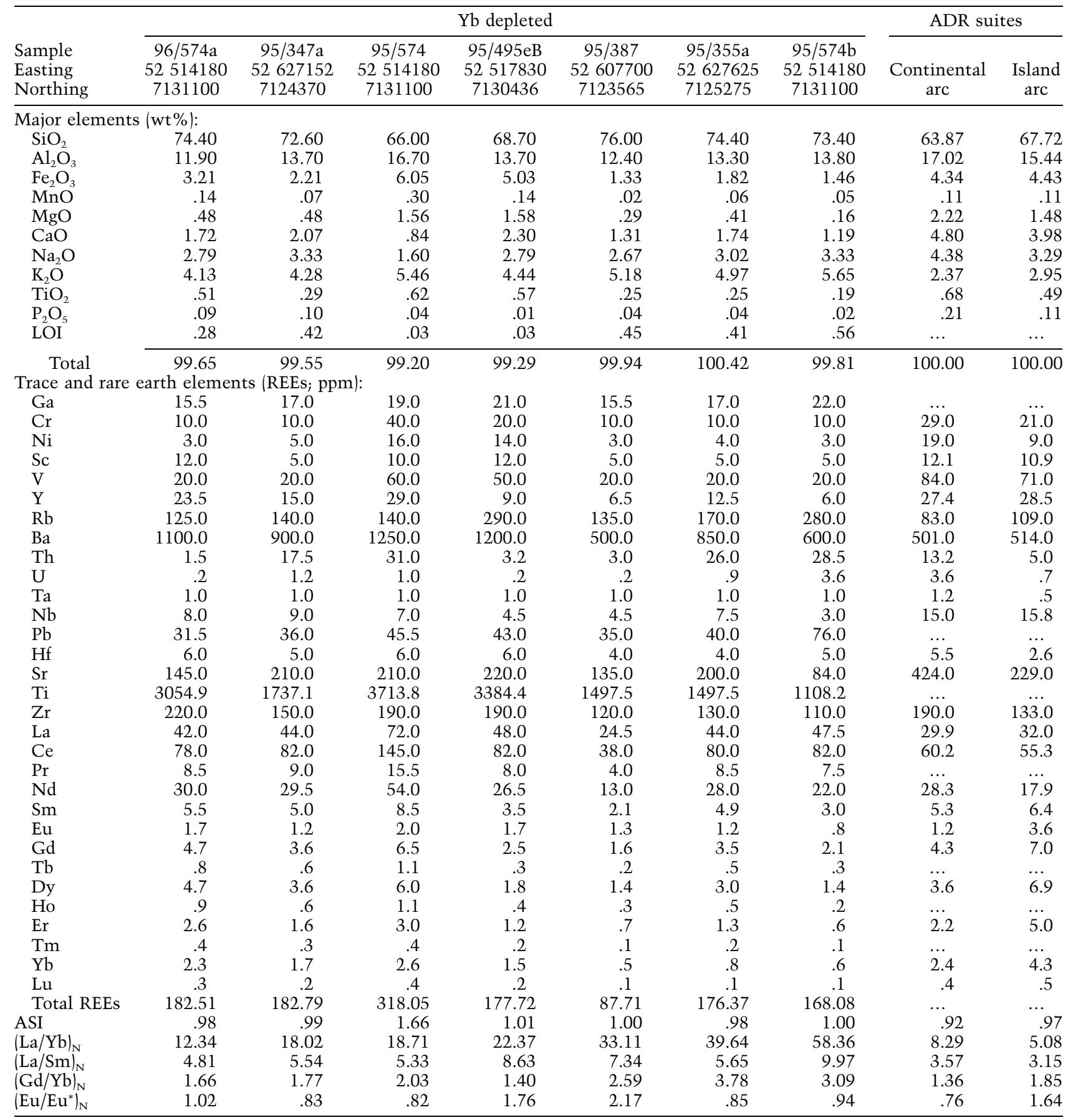

Note. $\quad$ LOI $=$ loss on ignition. ASI = aluminum saturation index.

exception being sample 96/574 from the Ybdepleted group, which has a peraluminous ASI value of 1.66 (table 2).

On a CIPW-normative Ab-An-Or classification diagram, the samples show a compositional variation defining a range of rock types from granitic to tonalitic (fig. $5 a$ ). Yb-enriched samples range in composition from quartz monzonites to tonalites, while $\mathrm{Yb}$-depleted samples cluster around the gran- ite/quartz monzonite boundary (fig. 5a). Samples from both $\mathrm{Yb}$-enriched and $\mathrm{Yb}$-depleted groups are of high-K composition, with one sample from the $\mathrm{Yb}$-enriched group plotting in the medium-K field (95/598; fig. 4).

The samples all fall within the calc-alkaline field defined in an AFM diagram, with the Yb-depleted samples plotting on a trend closer to the $\mathrm{Na}_{2} \mathrm{O}+$ $\mathrm{K}_{2} \mathrm{O}$ corner (fig. $5 b$ ). All samples exhibit $\mathrm{K}$ enrich- 
Table 3. Sm-Nd Isotopic Data for Felsic Rocks (from This Study)

\begin{tabular}{|c|c|c|c|c|c|c|c|c|c|c|}
\hline Sample & $(\mathrm{La} / \mathrm{Yb})_{\mathrm{N}}$ Group & $\begin{array}{c}\text { Est. Age } \\
\text { (Ma) }\end{array}$ & $\begin{array}{c}\mathrm{Nd} \\
(\mathrm{ppm})\end{array}$ & $\underset{(\mathrm{ppm})}{\mathrm{Sm}}$ & ${ }^{147} \mathrm{Sm} /{ }^{144} \mathrm{Nd}$ & ${ }^{143} \mathrm{Nd} /{ }^{144} \mathrm{Nd}$ & $2 \sigma^{\mathrm{a}}$ & $\varepsilon_{\mathrm{Nd}}(0)$ & $\varepsilon_{\mathrm{Nd}}(1550)$ & $T_{\mathrm{DM}}{ }^{\mathrm{b}}$ \\
\hline $95 / 598$ & Yb enriched & 1550 & 43.3 & 8.5 & .1188 & .511783 & 9 & -16.7 & -1.2 & 2169 \\
\hline $95 / 361$ & $\mathrm{Yb}$ enriched & $1548 \pm 28$ & 33.1 & 6.5 & .1189 & .511839 & 8 & -15.6 & -.2 & 2083 \\
\hline $95 / 168 b$ & $\mathrm{Yb}$ enriched & 1550 & 41.6 & 8.5 & .1236 & .511885 & 8 & -14.7 & -.2 & 2114 \\
\hline $95 / 472$ & $\mathrm{Yb}$ enriched & 1550 & 43.6 & 8.6 & .1199 & .511858 & 8 & -15.2 & .0 & 2074 \\
\hline $96 / 614$ & $\mathrm{Yb}$ enriched & 1550 & 38.3 & 7.8 & .1232 & .511891 & 9 & -14.6 & .0 & 2096 \\
\hline $95 / 402 c$ & $\mathrm{Yb}$ enriched & 1550 & 29.3 & 5.7 & .1185 & .511845 & 9 & -15.5 & .1 & 2065 \\
\hline $96 / 574 a$ & Yb depleted & 1550 & 30.8 & 5.8 & .1130 & .511772 & 9 & -16.9 & -.3 & 2062 \\
\hline $95 / 355 a$ & Yb depleted & 1550 & 30.5 & 5.2 & .1028 & .511706 & 10 & -18.2 & .5 & 1963 \\
\hline $95 / 387$ & Yb depleted & 1550 & 13.8 & 2.3 & .0996 & .511698 & 9 & -18.3 & .9 & 1921 \\
\hline
\end{tabular}

${ }^{a}$ Isotope error measurements are $2 \mathrm{SE} .{ }^{143} \mathrm{Nd} /{ }^{144} \mathrm{Nd}_{\mathrm{CHUR}}(0)=0.512638,{ }^{147} \mathrm{Sm} /{ }^{144} \mathrm{Nd}_{\mathrm{CHUR}}=0.1967$. CHUR $=$ chondritic uniform reservoir.

${ }^{\mathrm{b}}$ Depleted mantle model ages as per Goldstein et al. $(1984):{ }^{143} \mathrm{Nd} /{ }^{144} \mathrm{Nd}=0.51315,{ }^{147} \mathrm{Sm} /{ }^{144} \mathrm{Nd}=0.2145$.

ment closely following the calc-alkaline trend on a Na-K-Ca content diagram (fig. $5 c$ ).

Trace and Rare Earth Elements. Samples display a significant range in trace-element compositions. For consistency, $\mathrm{Yb}$ groups defined in the previous section have been adopted here. Broad negative correlations are seen in plots of $\mathrm{Zr}$ and $\mathrm{Sr}$ with $\mathrm{SiO}_{2}$ (fig. 4). Trace-element and REE spidergrams are normalized to primitive mantle and REE chrondrite values (fig. 6). In addition to the Musgrave samples, average trace-element and REE patterns for island arc and continental arc andesite-dacite-rhyolite (ADR) suites compiled by Drummond et al. (1996) are also shown in both figures; values for these can be found in table 2 .

The REE patterns for the $\mathrm{Yb}$-enriched and $\mathrm{Yb}$ depleted groups differ (fig. $6 a, 6 b$, respectively). Samples 95/495eB and 95/387 from the Yb-depleted group have marked positive $\mathrm{Eu}$ anomalies $\left(\left[\mathrm{Eu} / \mathrm{Eu}^{*}\right]_{\mathrm{N}}=1.76\right.$ and 2.17 , respectively). The majority of samples from the $\mathrm{Yb}$-enriched group have slightly positive to slightly negative $\mathrm{Eu}$ anomalies $\left(\left[\mathrm{Eu} / \mathrm{Eu}^{*}\right]_{\mathrm{N}}=0.63-1.11\right)$, while those from the $\mathrm{Yb}$ depleted group display slightly negative to no Eu anomalies $\left(\left[\mathrm{Eu} / \mathrm{Eu}^{*}\right]_{\mathrm{N}}=0.82-1.02\right.$; tables 1, 2; fig. $6 a, 6 b)$.

Yb-enriched samples display REE abundances that are typically 100 or more times greater for La and approximately 10-20 times greater for $\mathrm{Yb}$ (fig. 6a). All samples display enrichment in LREE/HREE $\left([\mathrm{La} / \mathrm{Yb}]_{\mathrm{N}}=\sim 5.9-10.3\right.$; table 1; fig. 6a). Samples display moderate amounts of light REE (LREE) fractionation, with $(\mathrm{La} / \mathrm{Sm})_{\mathrm{N}}$ from 2.9 to 4.4, and are weakly enriched in heavy REEs (HREEs), with $(\mathrm{Gd} / \mathrm{Yb})_{\mathrm{N}}$ from 1.1 to 1.5 (table 1 ; fig. $\left.6 a\right)$. When normalized to primitive mantle values, enrichments in $\mathrm{Rb}, \mathrm{Ba}$, and $\mathrm{K}$ are evident, with relative depletions in $\mathrm{Nb}, \mathrm{Sr}, \mathrm{P}, \mathrm{Ti}$, and $\mathrm{Yb}$ (fig. $6 c$ ).

$\mathrm{Yb}$-depleted samples display abundances in the range of 100 or more times greater for La and ap- proximately $2-10$ times greater for $\mathrm{Yb}$ (fig. $6 b$ ). The seven samples from this group all display extreme LREE enrichment, shown by their steep REE patterns and high $(\mathrm{La} / \mathrm{Yb})_{\mathrm{N}}$ values from 12 to 58 (table 2; fig. 6b). Yb-depleted samples display moderate to large amounts of LREE fractionation, with $(\mathrm{La} / \mathrm{Sm})_{\mathrm{N}}=4.8-10.0$, and are weakly enriched in HREEs, with $(\mathrm{Gd} / \mathrm{Yb})_{\mathrm{N}}=1.4-3.9$ (table 2; fig. $6 b$ ). Enrichments in $\mathrm{Rb}, \mathrm{Ba}$, and $\mathrm{K}$ are evident, with relative depletions in $\mathrm{Nb}, \mathrm{Sr}, \mathrm{P}, \mathrm{Ti}$, and $\mathrm{Yb}$ greater than those seen in $\mathrm{Yb}$-enriched samples (fig. 6d).

Sm-Nd Systematics. Table 3 displays $\varepsilon_{\mathrm{Nd}}$ values for nine samples analyzed from the Musgrave Block. Sample 95/361 has been directly dated by SHRIMP U-Pb and gave an age of $1548 \pm 28 \mathrm{Ma}$ (Scrimgeour et al. 1999). There is evidence of magmatic zircon growth in felsic rocks throughout the Musgrave Block spanning a time period of ca. 1.591.55 Ga (fig. 2; Camacho and Fanning 1995; Scrimgeour et al. 1999; Young et al. 2002). As a result, all $\varepsilon_{\mathrm{Nd}}$ values have been calculated at $1.55 \mathrm{Ga}$, which is the latest stage of crystallization obtained from zircon analysis. However, this age range exerts comparatively little effect on the $\varepsilon_{\mathrm{Nd}}$ values.

Six of the analyzed samples correspond to the $\mathrm{Yb}$ enriched group and three to the $\mathrm{Yb}$-depleted group. $\mathrm{Yb}$-enriched samples have slightly higher isotopic $\mathrm{Sm} / \mathrm{Nd}$ ratios, with values ranging from 0.1185 to 0.1236 , while $\mathrm{Yb}$-depleted samples have an isotopic $\mathrm{Sm} / \mathrm{Nd}$ range of 0.0996-0.1130. A tight range of measured ${ }^{143} \mathrm{Nd} /{ }^{144} \mathrm{Nd}$ values, from 0.511783 to 0.511891 , is displayed for $\mathrm{Yb}$-enriched samples, while $\mathrm{Yb}$-depleted samples have ${ }^{143} \mathrm{Nd} /{ }^{144} \mathrm{Nd}$ values ranging from 0.511698 to 0.511772 .

$\mathrm{Nd}$ isotopic data expressed as $\varepsilon_{\mathrm{Nd}}$ are plotted against age (in Ga) in figure 7 . Average crustal evolution lines for proximal basement terrains, including the Arunta Region to the north and Gawler Craton to the south of the Musgrave Block (fig. 1), are also shown in figure 7 . 


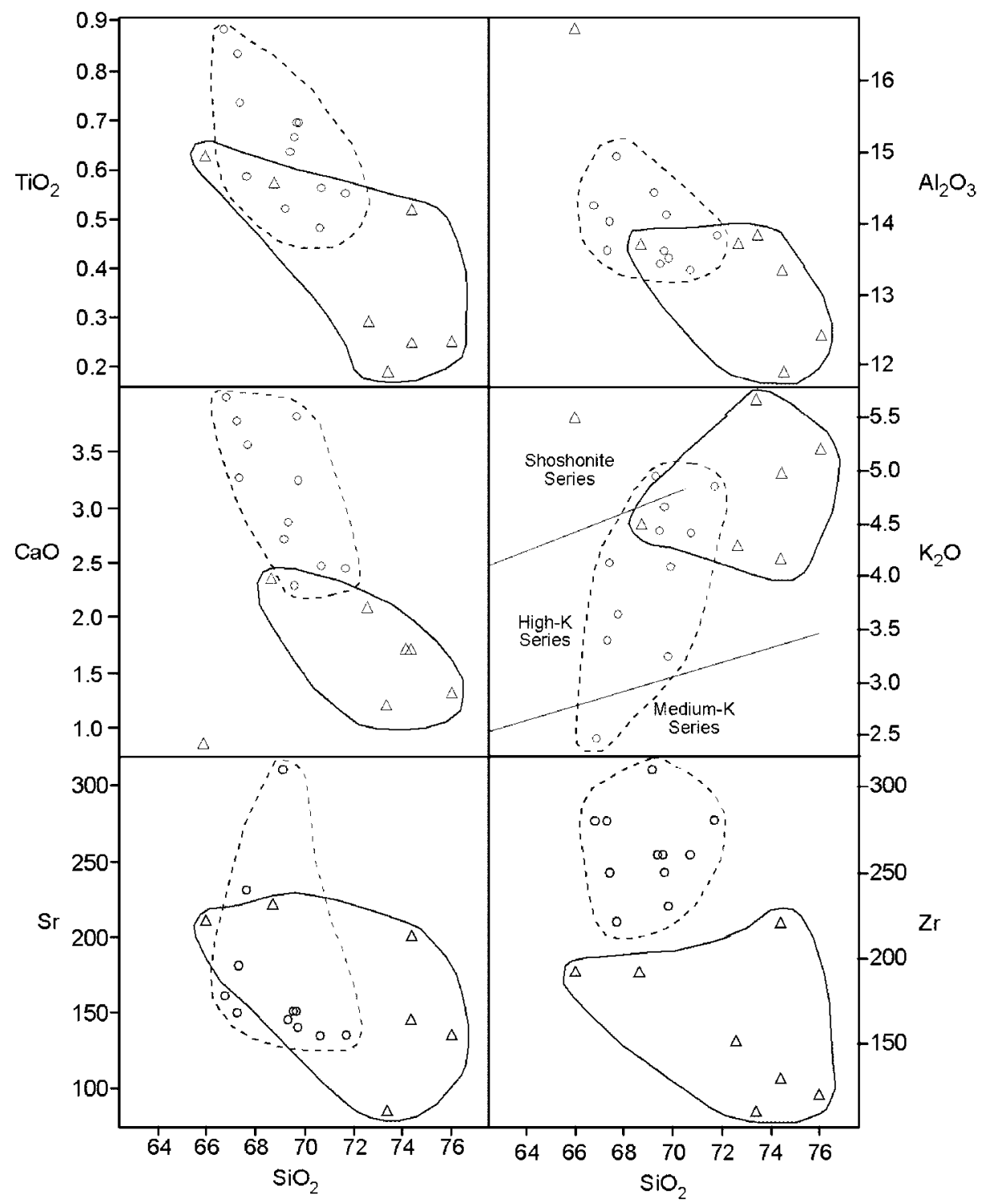

Figure 4. Harker variation diagrams and selected trace elements versus silica. Fields on $\mathrm{K}_{2} \mathrm{O}-\mathrm{SiO}_{2}$ plot are as per the classification diagram (Peccerillo and Taylor 1976). Circles, $(\mathrm{La} / \mathrm{Yb})_{\mathrm{N}}<12 ;$ triangles, $(\mathrm{La} / \mathrm{Yb})_{\mathrm{N}}>12$. Dashed lines designate $\mathrm{Yb}$-enriched samples; solid lines designate $\mathrm{Yb}$-depleted samples.

Samples exhibit negative to positive initial $\varepsilon_{\mathrm{Nd}}$ values of -1.2 to +0.9 , with most plotting around 0.0 (fig. 7). Despite the limited range of $\varepsilon_{\mathrm{Nd}}$ values, a broad correlation of $\mathrm{Yb}$ abundance with $\mathrm{Sm} / \mathrm{Nd}$ isotopic data is observed (table 3). The six samples from the $\mathrm{Yb}$-enriched group have an $\varepsilon_{\mathrm{Nd}}$ range of -1.2 to +0.1 , while the three samples from the $\mathrm{Yb}$ depleted group give a more positive range of -0.3 to +0.9 .

\section{Origin of the Ca. 1.6-1.55-Ga Felsic Rocks}

As a general rule, the $\mathrm{Yb}$-depleted group samples are deficient in $\mathrm{Al}_{2} \mathrm{O}_{3}, \mathrm{CaO}$, and $\mathrm{TiO}_{2}$, have ap- proximately the same $\mathrm{Na}_{2} \mathrm{O}$, and are enriched in $\mathrm{K}_{2} \mathrm{O}$ when compared with samples from the $\mathrm{Yb}$ enriched group (fig. 5; tables 1,2). The inverse correlation of $\mathrm{Al}_{2} \mathrm{O}_{3}, \mathrm{CaO}, \mathrm{TiO}_{2}, \mathrm{MgO}$, and $\mathrm{Fe}_{2} \mathrm{O}_{3}$ with silica reflects the role of plagioclase, pyroxene, and Fe-Ti oxides as major controlling phases (e.g., Whalen et al. 1999; Roberts et al. 2000). The positive correlation of $\mathrm{K}_{2} \mathrm{O}$ with silica is a common trend observed in felsic rocks because of fractionation of K-feldspar (e.g., Droux and Delaloye 1996; Roberts et al. 2000).

The granitic-tonalitic, medium-high-K composition of these rocks is directly comparable to those 


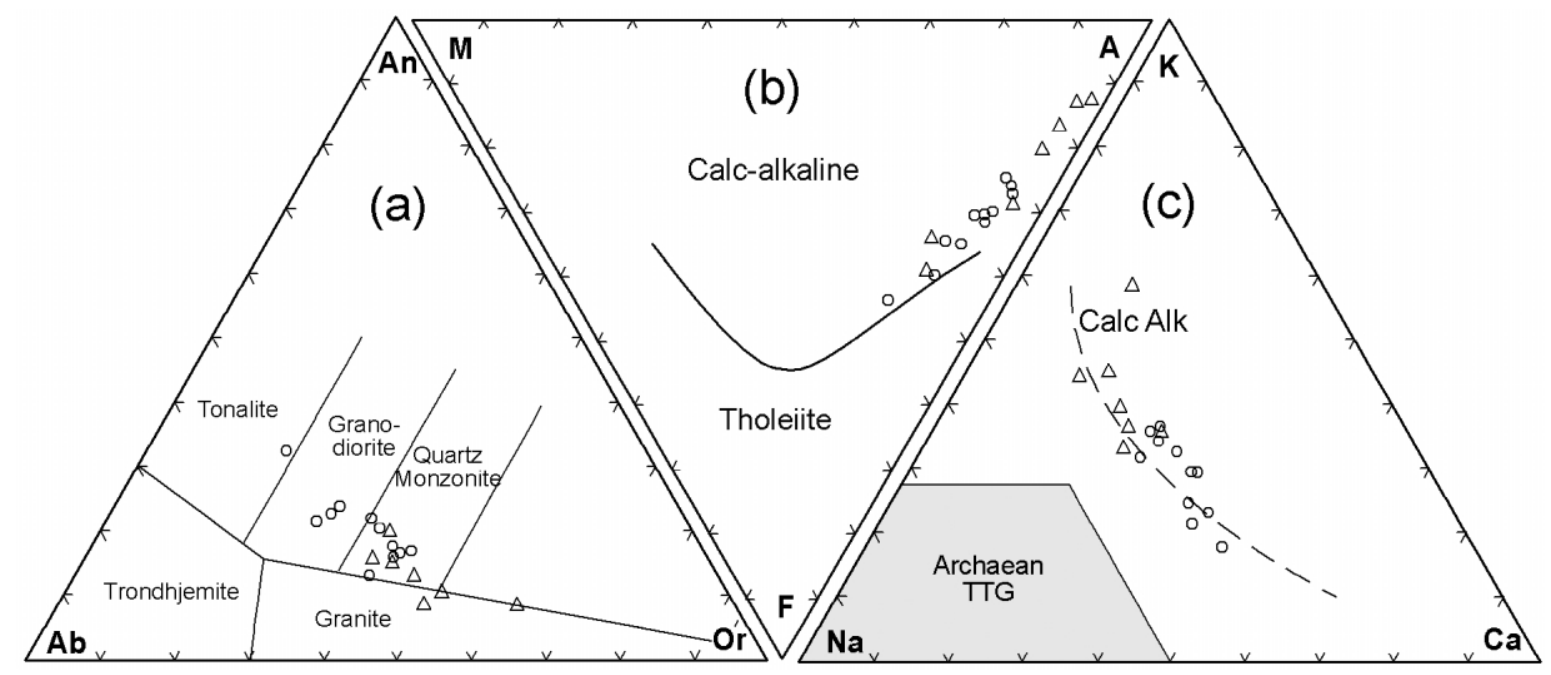

Figure 5. $a$, CIPW-normative Ab-An-Or classification diagram (after Barker 1979) for the silica groups. $b$, AFM diagram (after Irvine and Baragar 1971) for the silica groups. $c$, Molecular Na-K-Ca diagram for the silica groups. The shaded field denotes the Archean tonalite-trondhjemite-granodiorite association (Martin 1994), and the dashed line represents the calc-alkaline differentiation trend (Barker and Arth 1976). Symbols are as in figure 4.

of other calc-alkaline suites worldwide (e.g., Droux and Delaloye 1996; Roberts et al. 2000; Blein et al. 2003). Included in table 2 are average majorelement and trace-element geochemistry data for continental arc $(n=815)$ and island $\operatorname{arc}(n=473)$ ADR suites obtained from Drummond et al. (1996). The major-element compositions of the samples used in this study fit within these compiled data. The major-element composition of the samples displays similarities to those of other proposed Proterozoic calc-alkaline suites in central Australia, such as the Arunta calc-alkaline-trondhjemite group granites (Zhao 1992; Zhao and McCulloch 1995), and has similarities to those of globally recognized calc-alkaline suites such as those found in the Andes, the Trans-Hudson, and the French Pyrenees (e.g., Droux and Delaloye 1996; Dunphy and Ludden 1998; Roberts et al. 2000). While major elements are not ideal for tectonic discrimination of magmatic rocks, we can infer that the felsic rocks of the Musgrave Block display a general affinity to calc-alkaline rocks of other terrains worldwide.

The general negative correlations of $\mathrm{Sr}$ and $\mathrm{Zr}$ with increasing Si content indicate that these elements behaved compatibly during crystallization of the felsic series (fig. 4). Correlation of $\mathrm{V}$ with $\mathrm{TiO}_{2}$ (not shown) is suggestive of control by $\mathrm{Fe}-\mathrm{Ti}$ oxides, while positive correlation of $\mathrm{Sr}$ with $\mathrm{Al}_{2} \mathrm{O}_{3}$ and negative correlation with $\mathrm{Si}$ content are suggestive of control by plagioclase.

Residual Mineral Control on Trace-Element Compo- sition. When plotted normalized to primitive mantle values, common features between the two $\mathrm{Yb}$ groups are evident (fig. $6 c, 6 d$ ). Negative anomalies in $\mathrm{Nb}, \mathrm{P}, \mathrm{Ti}, \mathrm{Y}$, and $\mathrm{Yb}$ are common between the two groups, albeit to different degrees (fig. $6 c$, 6d).

Anomalies in both $\mathrm{Nb}$ and $\mathrm{Ti}$ are present in all samples and probably indicate that a residual titaniferous phase, such as rutile, was involved in the generation of both groups, as the subsequent extraction of the silicic melt is depleted in these elements. (e.g., Ellis 1992; Ellis and Maboko 1992). The slightly larger negative $\mathrm{Nb}$ anomaly in the $\mathrm{Yb}$ depleted group may indicate an increased role of rutile in the formation of the $\mathrm{Yb}$-depleted melts.

Both $\mathrm{Yb}$-enriched and $\mathrm{Yb}$-depleted groups display pronounced negative anomalies in $\mathrm{P}$, with the $\mathrm{Yb}$ depleted groups generally displaying slightly more negative excursions (fig. 6c, 6d). In previous studies, negative $\mathrm{P}$ anomalies have been attributed to control by residual apatite in the source (e.g., Hussain et al. 2004; Perini et al. 2004). This may indicate that residual apatite was in greater abundance in the source of the Yb-depleted melts, which may imply a heterogeneity in the source region.

The presence of a slightly negative to positive Eu anomaly in Yb-depleted samples and more pronounced negative $\mathrm{Eu}$ anomalies in $\mathrm{Yb}$-enriched samples may be explained by the role of plagioclase in the source. The retention of plagioclase in the slab residue of the source for $\mathrm{Yb}$-enriched samples 


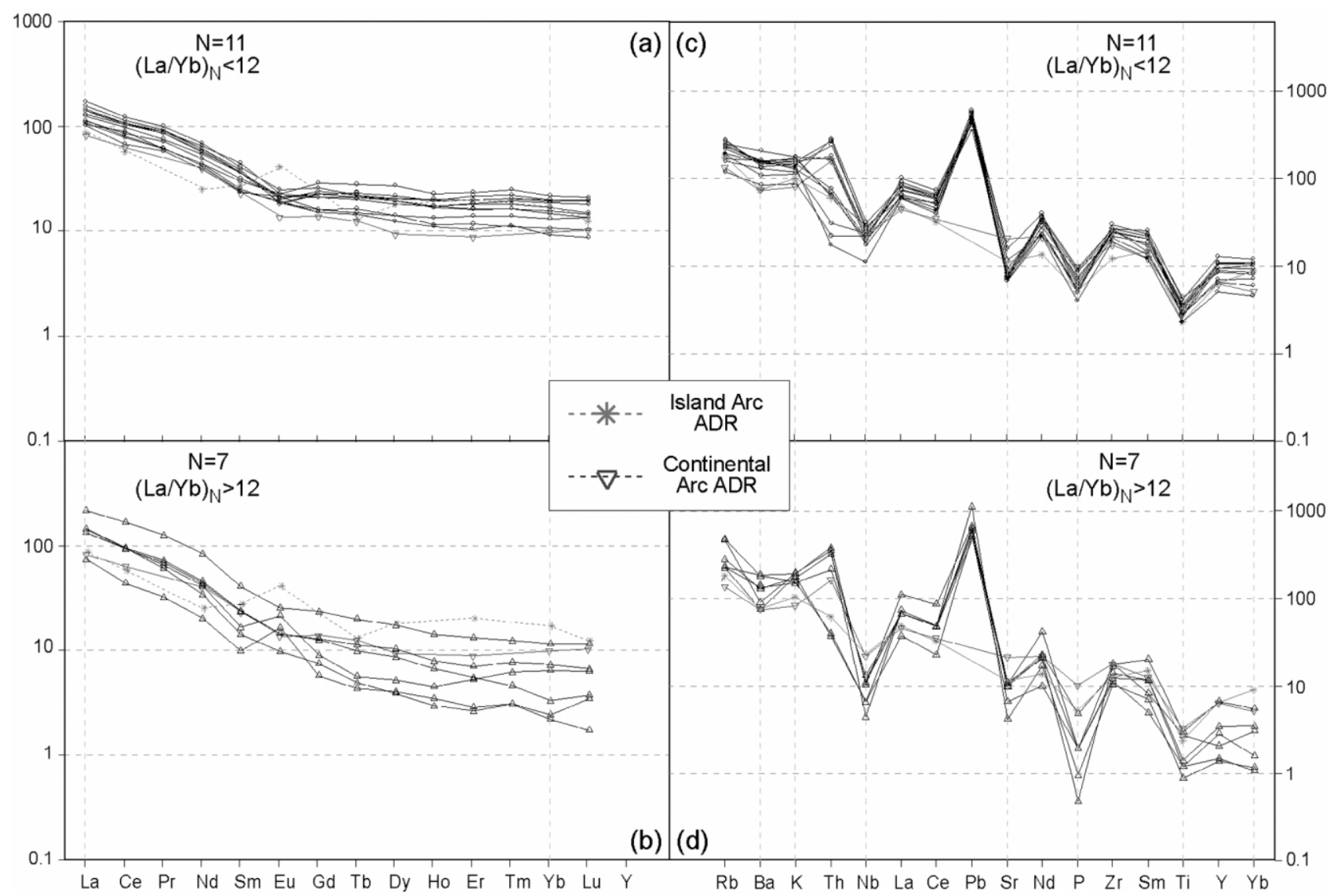

Figure 6. $\quad a, b$, Chondrite-normalized rare earth element plots for $(\mathrm{La} / \mathrm{Yb})_{\mathrm{N}}$-sorted groups. Normalizing values are from Taylor and McLennan (1985). c , d, Primitive mantle-normalized extended element plots for $(\mathrm{La} / \mathrm{Yb})_{\mathrm{N}}$-sorted groups. Normalizing values are from Sun and McDonough (1989). Included are patterns for island arc and continent arc andesite-dacite-rhyolite suites from Drummond et al. (1996).

and only minor residual plagioclase in the source for Yb-depleted samples could account for this (e.g., Bea 1996; Roberts et al. 2000; Perini et al. 2004).

The division between $\mathrm{Yb}$-enriched and $\mathrm{Yb}$ depleted groups is gradational (fig. 6). This is consistent with other studies involving arclike magmatic rocks, which have used such groupings to differentiate petrogenic and tectonic environments (e.g., Whalen et al. 1999). As a general rule, the $\mathrm{Yb}$ depleted group contains the more felsic end members of the samples (table 2) and, as a result, has the more fractionated REE patterns. However, the degree of fractionation in the REE pattern from the $\mathrm{Yb}$-enriched to the $\mathrm{Yb}$-depleted group is too great to explain by this simple fractionation, given the limited silica range of the samples $(\sim 65-76 \mathrm{wt} \%$; fig. $6 a, 6 b$; tables 1,2$)$.

Negative anomalies in $\mathrm{Y}$ and $\mathrm{Yb}$ have been interpreted as indicating residual garnet in the source region (e.g., Ellis and Maboko 1992; Wyborn 1992;
Drummond et al. 1996; Drummond and Defant 1990). The increasingly depleted nature of $Y$ and $\mathrm{Yb}$ for $\mathrm{Yb}$-depleted samples probably indicates that garnet was a major restitic phase in the source (fig. 6). Although a few samples from the Yb-enriched group display minor depletions in $\mathrm{Y}$, the majority suggest that little garnet, if any, was involved in their genesis. REEs are also partitioned by hornblende in equilibrated silicic magmas, and a negative $\mathrm{Y}$ anomaly could also reflect the presence of hornblende (Barker 1979; Martin 1986). The positive correlation of $\mathrm{Y}$ and $\mathrm{Nb}$ for $\mathrm{Yb}$-enriched samples and the scattered correlation for Yb-depleted samples (not shown) may indicate that hornblende removal played a dominant role in genesis of $\mathrm{Yb}$ enriched melts and a reduced role in $\mathrm{Yb}$-depleted melts. Also, given the steep slope of the REE pattern of the Yb-depleted group, the dominant mineral phase is assumed to be garnet, with hornblende playing a reduced role. 


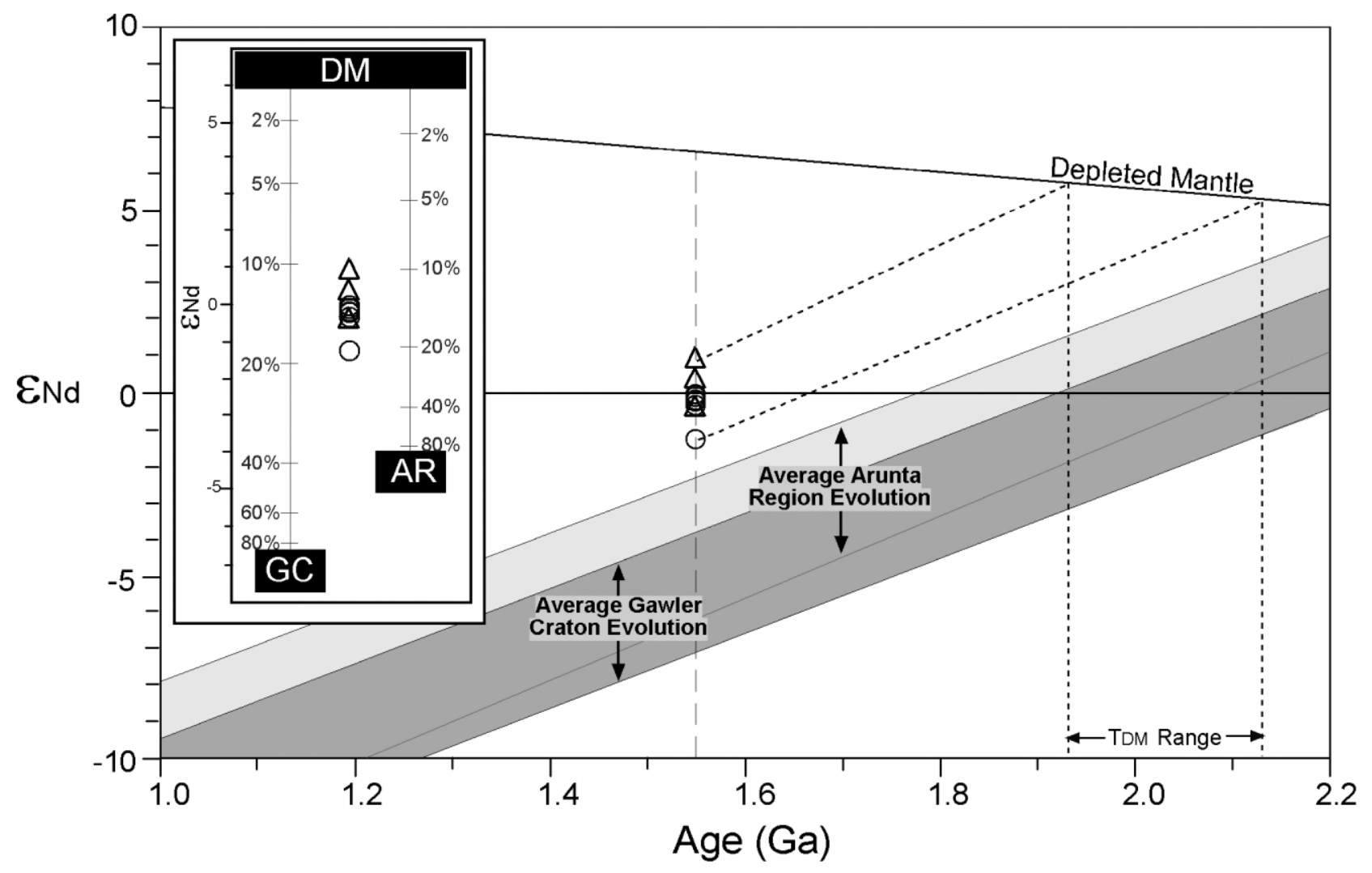

Figure 7. An $\varepsilon_{\mathrm{Nd}}$ evolution diagram displaying juvenile nature of the Musgrave felsic gneisses. Average basement evolution for the Gawler Craton (GC) is from Stewart (1992), Turner et al. (1993), Creaser (1995), and Schaefer (1998); for the Arunta Region (AR) from Foden et al. (1995), Sun et al. (1995), and Zhao and McCulloch (1995). Inset: Mixing calculations displaying required percentage of GC or AR contaminant to be added to the depleted mantle $(D M)$ to attain the range of $\varepsilon_{\mathrm{Nd}}$ values seen for Musgrave felsic rocks (estimated average $=30 \mathrm{ppm}$ for GC, $40 \mathrm{ppm}$ for AR, 4 ppm for DM; see text for discussion). Symbols are as in figure 4.

Tectonomagmatic Affinity. The general trend and position of the samples lie within the volcanic arc granite field of the $\mathrm{Rb}$ versus $\mathrm{Y}+\mathrm{Nb}$ Pearce plot (fig. 8; Pearce et al. 1984). A number of samples from the $\mathrm{Yb}$-enriched field cluster along the line of within-plate granites and volcanic and postcollisional granites and are characterized by having the highest HREE contents of all samples.

Caution must be taken when utilizing tectonic discrimination diagrams of this type, as the boundaries on these diagrams were determined using Phanerozoic granites, and it is still debated whether they can be applied to Proterozoic granites (e.g., Stewart 1992; Zhao 1992; Foerster et al. 1999). Other studies in the Australian Proterozoic have highlighted this potential limitation on plotting Australian Proterozoic granites on these tectonic discrimination diagrams (e.g., Stewart 1992; K. P. Stewart and J. D. Foden, unpublished manuscript). Arguments have been made that the trace elements used in these diagrams are controlled by accessory phases, which are in turn controlled by other complex magmatic parameters (e.g., Bea 1996; K. P. Stewart and J. D. Foden, unpublished manuscript).

Sm-Nd Systematics. The $\varepsilon_{\mathrm{Nd}}$ evolution of all samples is more juvenile than the evolution fields of crustal material that comprise the enclosing lithosphere (Gawler Craton and Arunta Region; fig. 7). This suggests either limited older crustal contamination or a juvenile preexisting Musgrave lithosphere with respect to the enclosing regions.

The inset in figure 7 shows the amount of mixing of both Gawler Craton and Arunta Region material with depleted mantle that would be required to produce the range of $\varepsilon_{\mathrm{Nd}}$ values calculated for the Musgrave felsic rocks at $1.55 \mathrm{Ga}$. Nd concentration estimates for the Gawler Craton and Arunta Region in the mixing calculations are 30 and $40 \mathrm{ppm}$, respectively (Gawler Craton: Stewart 1992; Turner et al. 1993; Creaser 1995; Schaefer 1998; Arunta Re- 


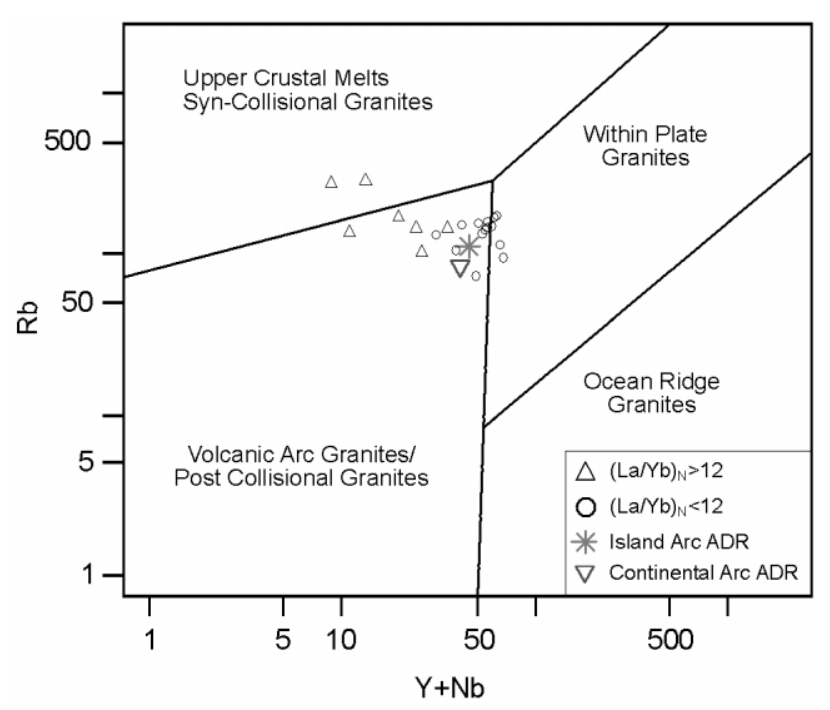

Figure 8. Geochemical tectonic classification diagrams (Pearce et al. 1984) for Musgrave Block felsic gneisses, illustrating their arc affinity.

gion: Foden et al. 1995; Sun et al. 1995; Zhao and McCulloch 1995). The Nd concentration of potential mantle-derived melts is not known. Attempts at characterization of normal midocean ridge basalt (N-MORB) sources have been carried out by various workers, with a $\mathrm{Nd}$ concentration of $5 \mathrm{ppm}$ suggested for a depleted mantle melt (e.g., Hofmann 1988; Hart et al. 1999). Hereafter, a Nd concentration of $5 \mathrm{ppm}$ is used in this study.

The mixing calculations argue for addition of only $\sim 10 \%-20 \%$ of Gawler Craton or Arunta Region crustal material to an N-MORB-like depleted mantle melt in order to attain the $\mathrm{Nd}$ isotopic signature of the Musgrave Complex felsic gneisses. The Nd concentration of the depleted mantle melt does have a bearing on this calculation, and as a result, other studies have used a range of concentrations between 5 and 15 ppm (e.g., Öhlander et al. 1999). However, a maximum concentration of $15 \mathrm{ppm} \mathrm{Nd}$ only increases the percentage of crustal addition from both terrains to $\sim 30 \%$. The felsic rocks are dominantly juvenile in origin and do not represent remelting of older continental crustal material.

However, a slightly more negative $\varepsilon_{\mathrm{Nd}}$ value $(-1.2$ for sample 95/598; table 3) may indicate the presence of an evolved Archean or Paleoproterozoic source. If this was the case, it was more likely to have been a contribution via slab sediment subduction rather than via crustal assimilation, given the absence of any inherited zircons older than ca. 1.6 Ga in the felsic rocks (e.g., Camacho and Fan- ning 1995; Scrimgeour et al. 1999; Young et al. 2002). These sediment sources could conceivably be the Gawler Craton to the south or the Arunta Region to the north (fig. 9). The apparent absence of an inherited zircon component in the felsic rocks further emphasizes that these felsic rocks probably represent formation of new juvenile crust at ca. 1.59-1.55 Ga, not anatectic melts formed through melting of crustal material. Similar conclusions have been reached from earlier work on the rocks in the western and northern Musgrave Block (Glikson et al. 1996; Scrimgeour et al. 1999).

\section{Petrogenetic and Tectonic Implications}

The 11 samples comprising the $\mathrm{Yb}$-enriched group closely resemble the oceanic arc average in both their REE and primitive mantle patterns, with corresponding relative amplitude depletions in elements discussed above (fig. 6). These patterns are typical of ADR arc-type suites and have been interpreted as indicating magma generation under relatively low pressure and dry melting conditions (Drummond et al. 1996). As discussed above, removal of plagioclase and hornblende played a dominant role in controlling the REE and trace-element patterns of Yb-enriched rocks. One possible scenario for generation of post-Archean magmatism of this type is via fusion of the mantle wedge, facilitated by fluids derived from dehydration of subducted lithosphere (Martin 1994).

Characteristic of samples from the Yb-depleted group are steep REE patterns and high depletions in $\mathrm{Nb}, \mathrm{P}, \mathrm{Ti}$, and $\mathrm{Y}$ (fig. $6 b, 6 d$ ). These depletions point to the removal of garnet, rutile, and, to a lesser extent, hornblende playing a dominant role, with no residual plagioclase (given the lack of negative Eu anomalies). In general, the geochemical features of the Yb-depleted group indicate derivation from a slab regime with elevated $P T$ conditions relative to the $\mathrm{Yb}$-enriched group. Studies have suggested that $P T$ conditions of $1.5-2.0 \mathrm{GPa}$ (50-60 $\mathrm{km})$ and $850^{\circ}-1150^{\circ} \mathrm{C}$ are required to generate melts of this type (Sen and Dunn 1994).

The trace-element and REE chemistry of both groups implies that partial melting occurred at different depths, with the Yb-enriched rocks representing melt generation at lithospheric levels shallower than those of the Yb-depleted rocks. This may indicate contemporaneous sourcing of melts at different lithospheric levels or a change in tectonic regime over a protracted period of time with multiple sourcing events. Without adequate age control, the temporal separation (if any) of the $\mathrm{Yb}$ enriched and $\mathrm{Yb}$-depleted rocks remains unknown. 

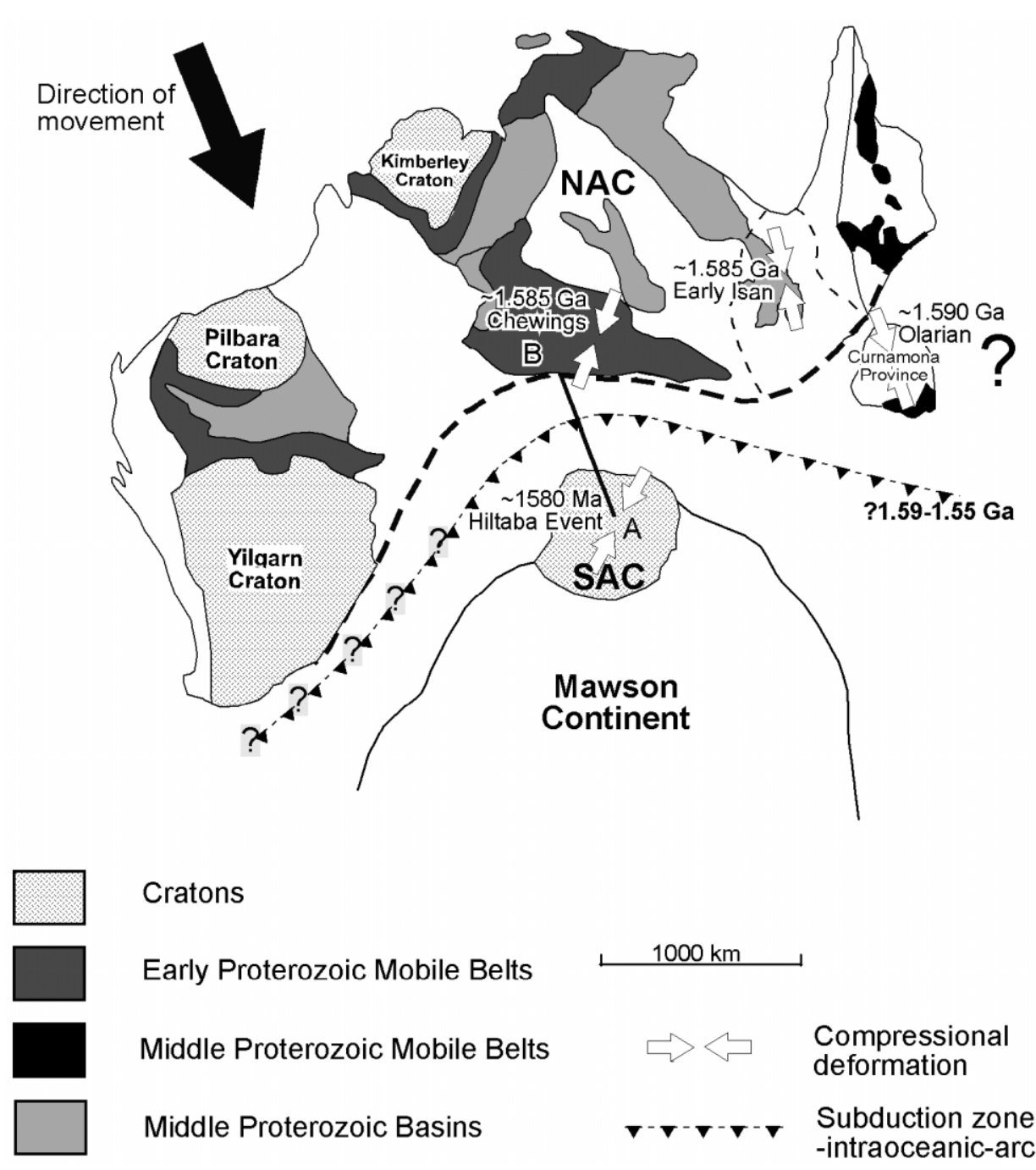

Cratons

Early Proterozoic Mobile Belts
Middle Proterozoic Mobile Belts
Middle Proterozoic Basins

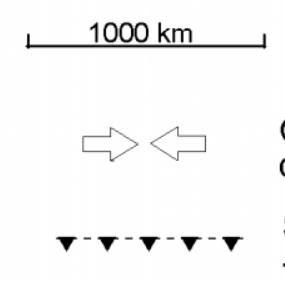

Compressional
deformation

Subduction zone -intraoceanic-arc

Figure 9. Reconstruction of Australia displaying presence of possible intraoceanic arc between northern Australian components and the South Australia Craton/Mawson Continent at various time periods. Cross section of line $A B$ is in figure 10.

However, from existing age data, it is not unreasonable to suggest that emplacement of the rocks via subduction processes occurred sometime in the interval of $\sim 1.59-1.55 \mathrm{Ga}$.

\section{Proterozoic Tectonic Evolution of the Musgrave Block}

The geochemical and isotopic data presented here suggest that the Mesoproterozoic history of the Musgrave Block is characterized by crustal addition in an island arc-like setting involving subductionrelated processes. The juvenile $\mathrm{Nd}$ isotopic characteristics of the samples, when coupled with REE and trace-element data, indicate that this arc may well have developed in an intraoceanic setting between the NAC and the SAC (fig. 9). The felsic gneisses and interlayered mafic rocks of the Musgrave Block are likely to represent the remnants of an arc terrane associated with suturing of the NAC with the SAC during 1.59-1.55 Ga. This age approximately coincides with a whole-rock $\mathrm{Sm} / \mathrm{Nd}$ isochron created from samples of the ca. 1.08-Ga Alcurra Dolerite, which gives an age of $1589 \pm$ $165 \mathrm{Ma}$ (Zhao and McCulloch 1993). Zhao and McCulloch interpreted these dolerite dikes as sampling an subcontinental lithospheric mantle that had been modified by crustal addition at $1.6 \mathrm{Ga}$. The proposed suturing of the NAC with the SAC at this time directly contradicts the inferred timing 
proposed by other workers (e.g., Myers et al. 1996; Giles et al. 2004; Şener et al. 2005). On the basis of piercing points between the two now separate entities, Giles et al. (2004) and Şener et al. (2005) have suggested suturing of the NAC with the SAC sometime in the interval ca. $1.8-1.5 \mathrm{Ga}$, the latter half of which overlaps with the late Kararan Orogeny of the Gawler Craton (Teasdale 1997; Daly et al. 1998). Neither model accounts for the genesis of the ca. 1.59-1.55-Ga felsic rocks of the Musgrave Block. If the ca. 1.59-1.55-Ga felsic rocks of the Musgrave Block are indeed derived from arc processes, as our study suggests, these models will require some modification. Listed below is a brief time line of events from ca. 1.60-1.55 Ga that we see as key in the formation of the Musgrave Block.

1.60-1.58 Ga. The extensive distribution of felsic material of this age in the Musgrave Block points to a major tectonothermal event in the Australian Proterozoic, with felsic rocks and/or deformation of this age found in the Gawler Craton, Arunta Region, Curnamona Province, and Mount Isa Inlier (e.g., Fanning et al. 1988; Page and Laing 1992; Collins and Shaw 1995; Young et al. 1995; Blewett et al. 1998; Page and Sun 1998; Page et al. 2000, 2003; Mark 2001).

The island arc system is interpreted as having initiated outboard of the Gawler Craton, forming the earliest components of the Musgrave Block. A proximal Gawler Craton is proposed to explain the slightly evolved $\mathrm{Nd}$ isotopic signature seen in the felsic samples, perhaps in the form of subducted near-margin sediments derived from the Gawler Craton.

Coeval with the development of the proposed island arc is the extrusion of voluminous rhyolites, dacites, and basalts of the ca. 1595-Ma Gawler Range Volcanics (GRVs) onto the Gawler Craton (Flint 1993; fig. 10a). The extrusion of the GRVs is classed as one of the world's largest felsic extrusive magmatic events, with the total area of the Gawler Craton affected by this felsic magmatism exceeding $100,000 \mathrm{~km}^{2}$ (Stewart 1992). The GRVs are interpreted in this study as representing an extensional magmatic event inboard of the south-dipping intraoceanic subduction system to the north.

The emplacement of the Hiltaba Suite at ca. 1.59-1.575 Ga occurred across much of the Gawler Craton (fig. 10b). The Hiltaba Suite may be an inboard expression of the south-dipping subduction to the north, much like the GRVs. Intrusion of the Hiltaba Suite in a compressional setting has recently been proposed (McLean and Betts 2003) and is interpreted in this study as resulting from the stresses formed by the encroaching NAC continen- tal fragment from the north. Regional north-south compressional metamorphism in this time period is seen over much of the NAC, including the 1.5951.57-Ga Chewings Orogeny (e.g., Collins and Shaw 1995; Young et al. 1995; Williams et al. 1996; Hand and Buick 2001; Rubatto et al. 2001) and the $\sim 1.585$-Ga early Isan Orogeny (e.g., Page and Sun 1998; Giles and Nutman 2002). Deformation of this age is also manifest in the Curnamona Province as the compressional Olarian Orogeny at $\sim 1.59 \mathrm{Ga}$ (fig. 9; Page and Laing 1992; Page et al. 2000, 2003).

$<\mathbf{1 . 5 8}$ Ga. Closure of the oceanic system between the northern Gawler Craton and southern Arunta resulted in the accretion and subsequent amalgamation of the island arc terrain between these continental masses (fig. 10c). Metamorphism in the central Musgrave Block at $1.55 \mathrm{Ga}$ has been proposed by Camacho (1997). Deformation and associated metamorphism of this age is found throughout the Gawler Craton and the NAC (e.g., Connors and Page 1995; Fanning 1995; Black et al. 1998; Daly et al. 1998). Metamorphism has recently been identified at ca. $1.55 \mathrm{Ga}$ in the Georgetown Inlier (e.g., Fanning 1995; Black et al. 1998) and at ca. 1.54 Ga in the Mount Isa Inlier (Connors and Page 1995). High-grade compressional granulitegrade metamorphism in the northern Gawler Craton at this time has also been documented, at ca. 1.565 Ga in the Coober Pedy Ridge and ca. 1.54 Ga in the Mabel Creek Ridge (Daly et al. 1998). Continental collision and arc closure at this time might be recorded in northern parts of the Gawler Craton; however, because of extensive cover, the geological history of this region remains largely unknown.

Collision at ca. 1.59-1.55 Ga, in turn, has important tectonic implications for the ca. 1.3-1.1-Ga Musgrave Orogeny. The Musgrave and AlbanyFraser orogenies have been interpreted in the past as the result of collision of the combined NAC and WAC with the SAC, beginning around $\sim 1.30 \mathrm{Ga}$ and continuing to $\sim 1.17 \mathrm{Ga}$ (Myers et al. 1996). Earlier collision and suturing of the combined NAC and WAC with the SAC at 1.8-1.5 Ga, followed by rifting and subsequent suturing at ca. 1.3-1.1 Ga, has also been suggested as an alternative (Giles et al. 2004). The presence of $\sim 1.59-1.55-\mathrm{Ga}$ arclike rocks in the Musgrave Block indicates that the docking of the NAC with the SAC may have occurred at an earlier stage, with subsequent rifting and collision again at ca. 1.3-1.1 Ga. In the AlbanyFraser Orogeny, there is no evidence to date of tectonic or magmatic activity at ca. 1.59-1.55 Ga. Nelson et al. (1995), however, interpreted the ca. 1.71.6-Ga felsic rocks of the Albany-Fraser Orogen to be arclike, with the collision of the WAC and SAC 


\section{ca.1.60-1.595 Ga}

Gawler Range Volcanics

- initiation of island arc (proto-Musgraves) outboard of Archaean Gawler

- Rhyolites, dacites, and basalts of the GRV intrude and extrude the Gawler

- GRV is extensional inboard expression of outboard south-dipping subduction

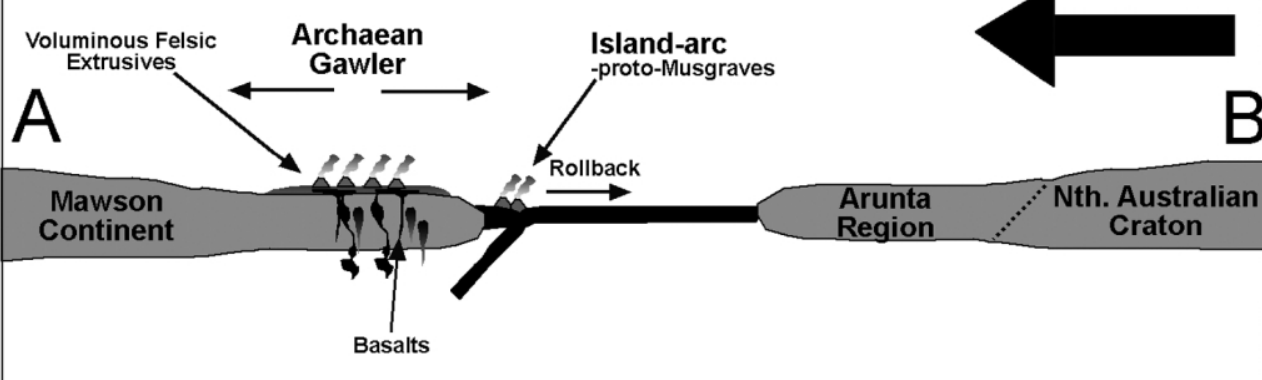

\section{ca.1.595-1.58 Ga}

Hiltaba Event/Musgraves

- Hiltaba event becomes compressional inboard expression of south-dipping subduction

- back-stepping of island-arc

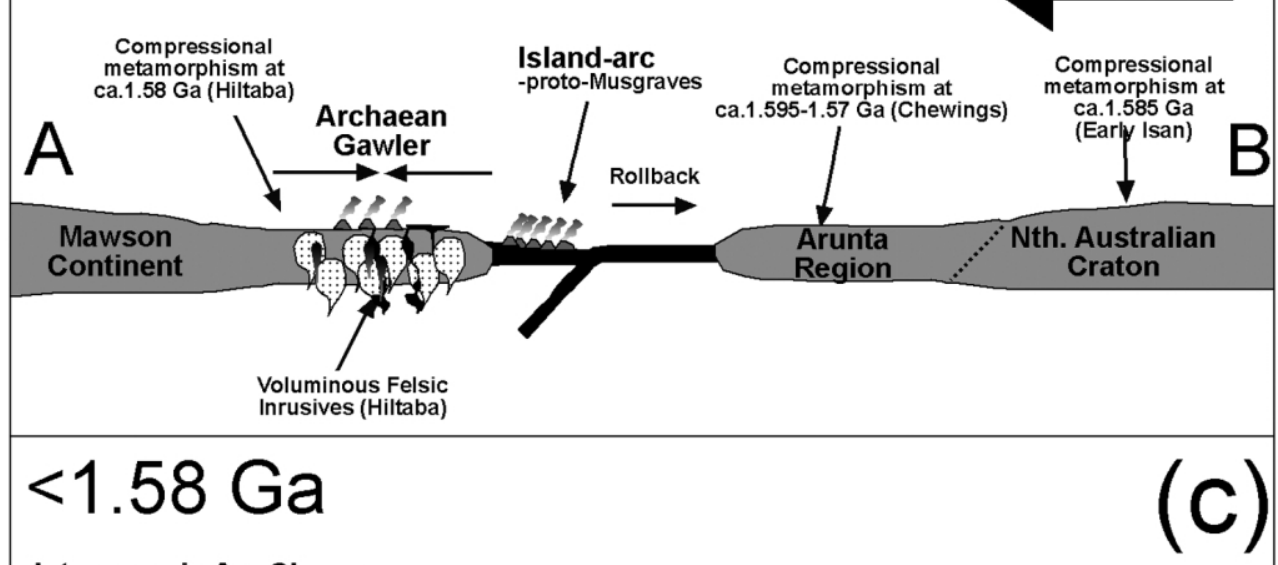

Intraoceanic Arc Closure

- closure of ocean

- compression and accretion of arc chains between Gawler Craton and Arunta Region

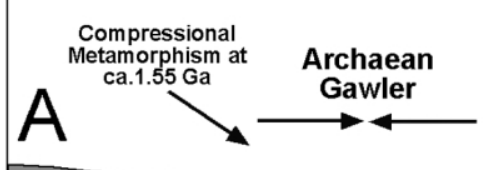

Closure and accretion

of island-arcs
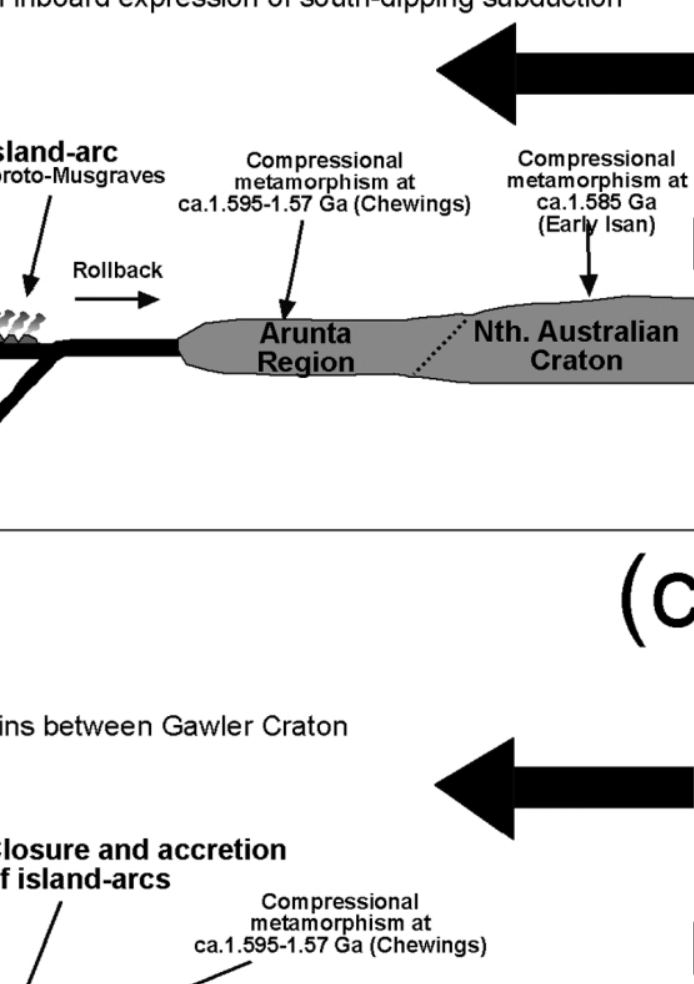

Mawson

Continent
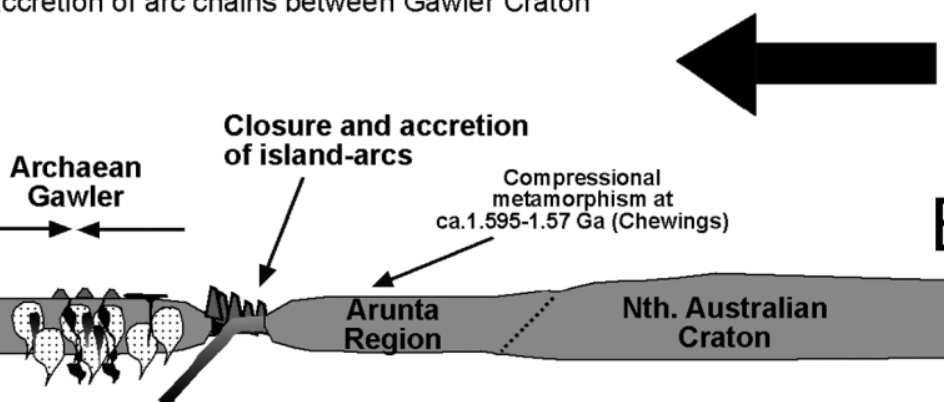

Figure 10. Cross sections of possible plate reconstructions at various time periods. Transect $A-B$ is detailed in figure 9 . 
invoked by Clark et al. (2000) between ca. 1.35 and $1.26 \mathrm{Ga}$. Clearly, the arc magmatic and tectonic events documented in the Musgrave Block are part of a series of complicated events throughout the Musgrave and Albany-Fraser regions extending back to ca. 1.7 Ga (Nelson et al. 1995).

\section{Summary}

The geological evolution of the Musgrave Block involves magmatic arc development in processes similar to those described for Proterozoic terranes in Laurentia and the Baltic Shield (e.g., Hoffman 1980; Lewry 1981; Condie 1982; Park 1985; Dickin and McNutt 1990; Snyder et al. 1996; Torsvik et al. 1996; Patchett and Chase 2002; Steltenpohl et al. 2003). Nd isotopic data indicate a juvenile signature and suggests minor crustal contamination, possibly by sediment subduction.
The Musgrave Block arc rocks and coeval ca. 1.58-Ga tectonothermal events that affected the NAC and the SAC developed 200 m.yr. later than the well-characterized ca. 2.0-1.8-Ga period of global crustal growth in other parts of the world. These results suggest that major periods of crustal growth and amalgamation may have spanned a larger age range in Proterozoic Australia than elsewhere in the world.

\section{A C K N O W L E D G M E N T S}

C. Edgoose is thanked for discussions and involvement in mapping of the Mann Ranges. Funding for this project was provided by Australian Research Council Discovery grant DP0345626 and financial contribution from the Primary Industries and Resources of South Australia.

\section{R E F E R E N C E S C I T E D}

Barker, F. 1979. Trondhjemite: definition, environment and hypotheses of origin. In Barker, F., ed. Trondhjemites, dacites, and related rocks. Amsterdam, Elsevier, p. 1-12.

Barker, F., and Arth, J. G. 1976. Generation of trondhjemite-tonalitic liquids and Archean bimodal trondhjemite-basalt suites. Geology 4:596-600.

Bea, F. 1996. Residence of REE, Y, Th and U in granites and crustal protoliths; implications for the chemistry of crustal melts. J. Petrol. 37:521-552.

Betts, P. G.; Giles, D.; Lister, G. S.; and Frick, L. R. 2002. Evolution of the Australian lithosphere. Aust. J. Earth Sci. 49:661-695.

Black, L. P.; Gregory, P.; Withnall, I. W.; and Bain, J. H. C. 1998. U-Pb zircon age for the Etheridge Group, Georgetown region, North Queensland: implications for relationship with the Broken Hill and Mt. Isa sequences. Aust. J. Earth Sci. 45:925-935.

Black, L. P.; Harris, L. B.; and Delor, C. P. 1992. Reworking of Archaean and Early Proterozoic components during a progressive, middle Proterozoic tectonothermal event in the Albany Mobile Belt, Western Australia. Precambrian Res. 59:95-123.

Blein, O.; LaFleche, M. R.; and Corriveau, L. 2003. Geochemistry of the granulitic Bondy gneiss complex: a 1.4 Ga arc in the Central Metasedimentary Belt, Grenville Province, Canada. Precambrian Res. 120:193217.

Blewett, R. S.; Black, L. P.; Sun, S.-S.; Knutson, J.; Hutton, L. J.; and Bain, J. H. C. 1998. U-Pb zircon and Sm-Nd geochronology of the Mesoproterozoic of North Queensland: implications for a Rodinian connection with the Belt supergroup of North America. Precambrian Res. 89:101-127.

Camacho, A. 1997. An isotopic study of deep-crustal oro- genic processes, Musgrave Block, central Australia. Ph.D. dissertation, Australian National University, Canberra.

Camacho, A.; Compston, W.; McCulloch, M.; and McDougall, I. 1997. Timing and exhumation of eclogite facies shear zones, Musgrave Block, central Australia. J. Metamorph. Geol. 15:735-751.

Camacho, A., and Fanning, C. M. 1995. Some isotopic constraints on the evolution of the granulite and upper amphibolite facies terranes in the eastern Musgrave Block, central Australia. Precambrian Res. 71:155181.

Camacho, A., and McDougall, I. 2000. Intracratonic, strike-slip partitioned transpression and the formation and exhumation of eclogite facies rocks: an example from the Musgrave Block, central Australia. Tectonics 19:978-996.

Cawood, P. A., and Tyler, I. M. 2004. Assembling and reactivating the Proterozoic Capricorn Orogen: lithotectonic elements, orogenies, and significance. Precambrian Res. 128:201-218.

Clark, D. J.; Hensen, B. J.; and Kinny, P. D. 2000. Geochronological constraints for a two-stage history of the Albany-Fraser Orogen, Western Australia. Precambrian Res. 102:155-183.

Clark, D. J.; Kinny, P. D.; Post, N. J.; and Hensen, B. J. 1999. Relationships between magmatism, metamorphism and deformation in the Fraser Complex, Western Australia; constraints from new SHRIMP U-Pb zircon geochronology. Aust. J. Earth Sci. 46:923-932.

Clarke, G. L.; Buick, I. S.; Glikson, A. Y.; and Stewart, A. J. 1995. Structural and pressure-temperature evolution of host rocks of the Giles Complex, central Australia: evidence for multiple high pressure events. AGSO J. Aust. Geol. Geophys. 16:127-146. 
Close, D. F.; Scrimgeour, I. R.; Edgoose, C. J.; and Cross, A. 2004. Late Palaeoproterozoic development of the SW margin of the North Australian Craton. In McPhie, J., and McGoldrick, P., eds. Dynamic earth: past, present and future. Geol. Soc. Aust. Abstr. 73:149.

Collins, W. J., and Shaw, R. D. 1995. Geochronological constraints on orogenic events in the Arunta Inlier: a review. Precambrian Res. 71:315-346.

Condie, K. C. 1982. Plate-tectonics model for Proterozoic continental accretion in the southwestern United States. Geology 10:37-42.

Connors, K. A., and Page, R. W. 1995. Relationships between magmatism, metamorphism and deformation in the western Mount Isa Inlier, Australia. Precambrian Res. 71:131-153.

Conor, C. H. H. 1987. The geology of the Eateringinna 1 : 100,000 sheet area, eastern Musgrave Block, South Australia. M.S. thesis, University of Adelaide.

Creaser, R. A. 1995. Neodymium isotopic constraints for the origin of Mesoproterozoic felsic magmatism, Gawler Craton, South Australia. Can. J. Earth Sci. 32:460471.

Daly, S. J.; Fanning, C. M.; and Fairclough, M. C. 1998. Tectonic evolution and exploration potential of the Gawler Craton. AGSO J. Aust. Geol. Geophys. 17: 145-168.

Dickin, A. P., and McNutt, R. H. 1990. Nd model-age mapping of Grenville lithotectonic domains; midProterozoic crustal evolution in Ontario. In Gower, C. F.; Rivers, T.; and Ryan, B., eds. Mid-Proterozoic Laurentia-Baltica. Geol. Assoc. Can. Spec. Pap. 38. St. John's, Geol. Assoc. Can., p. 79-94.

Droux, A., and Delaloye, M. 1996. Petrography and geochemistry of Plio-Quaternary calc-alkaline volcanoes of southwestern Colombia. J. S. Am. Earth Sci. 9:2741.

Drummond, M. S., and Defant, M. J. 1990. A model for trondhjemite-tonalite-dacite genesis and crustal growth via slab melting: Archean to modern comparisons. J. Geophys. Res. 95:21,503-21,521.

Drummond, M. S.; Defant, M. J.; and Kepezhinskas, P. K. 1996. Petrogenesis of slab-derived trondhjemitetonalite-dacite/adakite magmas. Trans. R. Soc. Edinb. $87: 205-215$.

Dunphy, J. M., and Ludden, J. N. 1998. Petrological and geochemical characteristics of a Paleoproterozoic magmatic arc (Narsajuaq terrane, Ungava Orogen, Canada) and comparisons to Superior Province granitoids. Precambrian Res. 91:109-142.

Edgoose, C. J.; Camacho, A.; Wakelin-King, G. W.; and Simons, B. 1993. Kulgera, N. T. Northern Territory Geological Survey sheet SG53-5 explanatory notes. Darwin, Northern Territory Geol. Surv., scale $1: 250,000$.

Edgoose, C. J.; Scrimgeour, I. R.; and Close, D. F. 2004. Geology of the Musgrave Block, Northern Territory. Northern Territory Geol. Surv. Rep. 15.

Ellis, D. J. 1992. Precambrian tectonics and the physiochemical evolution of the continental crust. II. Lith- osphere delamination and ensialic orogeny. Precambrian Res. 55:507-524.

Ellis, D. J., and Maboko, M. A. H. 1992. Precambrian tectonics and the physiochemical evolution of the continental crust. I. The gabbro-eclogite transition revisited. Precambrian Res. 55:491-506.

Etheridge, M. A.; Rutland, R. W. R.; and Wyborn, L. A. I. 1987. Orogenesis and tectonic process in the early to middle Proterozoic of northern Australia. In A. Kröner, ed. Proterozoic lithospheric evolution. Washington, DC, Am. Geophys. Union, p. 131-147.

Fanning, C. M. 1995. Geochronological synthesis of southern Australia. Pt. 1. The Curnamona Province. Mines and Energy South Australia Open File Env. 8918 R1:3-22.

Fanning, C. M.; Flint, R. B.; Parker, A. J.; Ludwig, K. R.; and Blisset, A. H. 1988. Refined Proterozoic evolution of Gawler Craton, southern Australia, through U-Pb zircon geochronology. Precambrian Res. 40/41:363380.

Fanning, C. M.; Moore, D. H.; Bennett, V. C.; and Daly, S. J. 1996. The "Mawson Continent"; Archaean to Proterozoic crust in the East Antarctic shield and Gawler craton, Australia: a cornerstone in Rodinia and Gondwanaland. Geol. Soc. Aust. Abstr. 41:135.

Flint, R. B. 1993. Mesoproterozoic. In Drexel, J. F.; Preiss, W. V.; and Parker, A. J., eds. The geology of South Australia. Vol. 1. The Precambrian. Geol. Surv. S. Aust. Bull. 54:107-169.

Foden, J.; Mawby, J.; Kelley, S.; Turner, S.; and Bruce, D. 1995. Metamorphic events in the eastern Arunta Inlier. Pt. 2. Nd-Sr-Ar isotopic constraints. Precambrian Res. 71:207-227.

Foden, J. D.; Buick, I. S.; and Mortimer, G. E. 1988. The petrology and geochemistry of granitic gneisses from the East Arunta Inlier, central Australia: implications for Proterozoic crustal development. Precambrian Res. 40/41:233-259.

Foerster, H. J.; Tischendorf, G.; Trumbull, R. B.; and Gottesmann, B. 1999. Late-collisional granites in the Variscan Erzgebirge, Germany. J. Petrol. 40:1613-1645.

Gee, R. D. 1979. Structure and tectonic style of the Western Australian Shield. Tectonophysics 58:327-369.

Giles, D.; Betts, P; and Lister, G. 2002. Far-field continental backarc setting for the 1.80-1.67 Ga basins of northeastern Australia. Geology 30:823-826.

- 2004. 1.8-1.5-Ga links between the North and South Australian Cratons and the Early-Middle Proterozoic configuration of Australia. Tectonophysics 380:27-41.

Giles, D., and Nutman, A. P. 2002. SHRIMP U-Pb monazite dating of 1600-1580 Ma amphibolite facies metamorphism in the southeastern Mt. Isa Block, Australia. Aust. J. Earth Sci. 49:455-465.

Glikson, A. Y.; Ballhaus, C. G.; Clarke, G. L.; Sheraton, J. W.; Stewart, A. J.; and Sun, S.-S. 1995. Geological framework and crustal evolution of the Giles maficultramafic complex and environs, western Musgrave Block, central Australia. AGSO J. Aust. Geol. Geophys. 16:41-67. 
Glikson, A. Y.; Stewart, A. J.; Ballhaus, C. G.; Clarke, G. L.; Feeken, E. H. J.; Leven, J. H.; Sheraton, J. W.; and Sun, S.-S. 1996. Geology of the western Musgrave Block, central Australia, with particular reference to the mafic-ultramafic Giles complex. AGSO Bull. 239: 41-68.

Goldstein, S. L.; O'Nions, R. K.; and Hamilton, P. J. 1984. A Sm-Nd isotopic study of atmospheric dusts and particulates from major river systems. Earth Planet. Sci. Lett. 70:221-236.

Gorton, M. P., and Schandl, E. S. 2000. From continents to island arcs: a geochemical index of tectonic setting for arc-related and within-plate felsic to intermediate volcanic rocks. Can. Mineral. 38:1065-1073.

Gray, C. M. 1978. Geochronology of granulite-facies gneisses in the western Musgrave Block, Central Australia. J. Geol. Soc. Aust. 25:403-414.

Hand, M., and Buick, I. S. 2001. Tectonic evolution of the Reynolds-Anmatjira ranges: a case study in terrain reworking from the Arunta Inlier, central Australia. In Miller, J. A.; Holdsworth, R. E.; Buick, I. S.; and Hand, M., eds. Continental reactivation and reworking. London, Geol. Soc. Lond., p. 237-260.

Hart, S. R.; Blusztajn, J.; Dick, H. J. B.; Meyer, P. S.; and Muehlenbachs, K. 1999. The fingerprint of seawater circulation in a 500-meter section of ocean crust gabbros. Geochim. Cosmochim. Acta 63:4059-4080.

Hoffman, P. F. 1980. Wopmay Orogen: a Wilson cycle of early Proterozoic age in the northwest of the Canadian Shield. Geol. Assoc. Can. Spec. Pap. 20. St. John's, Geol. Assoc. Can., p. 523-549.

- 1988. United plates of America, the birth of a craton: early Proterozoic assembly and growth of Laurentia. Annu. Rev. Earth Planet. Sci. 16:543-603.

Hofmann, A. W. 1988. Chemical differentiation of the Earth: the relationship between mantle, continental crust, and oceanic crust. Earth Planet. Sci. Lett. 90: 297-314.

Hussain, M. F.; Mondal, M. E. A.; and Ahmad, T. 2004. Petrological and geochemical characteristics of Archean gneisses and granitoids from Bastar Craton, central India: implication for subduction related magmatism. Gondwana Res. 7:531-537.

Irvine, T. N., and Baragar, W. R. A. 1971. A guide to the chemical classification of the common volcanic rocks. Can. J. Earth Sci. 8:523-548.

Johannes, W.; Holtz, F.; and Möller, P. 1995. REE distribution in some layered migmatites: constraints on their petrogenesis. Lithos 35:139-152.

Kepezhinskas, P. K.; McDermott, F.; Defant, M. J.; Hochstaedter, A. G.; Drummond, M. S.; Hawkesworth, C. J.; Koloskov, A. V.; Maury, R. C.; and Bellon, H. 1997. Trace element and $\mathrm{Sr}-\mathrm{Nd}-\mathrm{Pb}$ isotopic constraints on a three-component model of Kamchatka Arc petrogenesis. Geochim. Cosmochim. Acta 61:577-600.

Lewry, J. F. 1981. Lower Proterozoic arc-microcontinent collisional tectonics in the western Churchill Province. Nature 294:69-72.

Maboko, M. A. H. 1988. Metamorphic and geochronological evolution in the Musgrave Ranges, central
Australia. Ph.D. dissertation, Australian National University, Canberra.

Maboko, M. A. H.; Williams, I. S.; and Compston, W. 1991. Zircon U-Pb chronometry of the pressure and temperature history of granulites in the Musgrave Ranges, central Australia. J. Geol. 99:675-697.

Mark, G. 2001. Nd isotope and petrogenetic constraints for the origin of the Mount Angelay igenous complex: implications for the origin of intrusions in the Cloncurry district, NE Australia. Precambrian Res. 105:1735.

Martin, H. 1986. Effects of steeper Archean geothermal gradient on geochemistry of subduction-zone magmas. Geology 14:753-756.

1994. The Archean grey gneisses and the genesis of continental crust. In Condie, K. C., ed. Archean crustal evolution. New York, Elsevier, p. 205-258.

McDonald, G. D.; Collerson, K. D.; and Kinny, P. D. 1997. Late Archean and early Proterozoic crustal evolution of the Mount Isa Block, Northwest Queensland, Australia. Geology 25:1095-1098.

McLean, M. A., and Betts, P. G. 2003. Geophysical constraints of shear zones and geometry of the Hiltaba Suite granites in the western Gawler Craton, Australia. Aust. J. Earth Sci. 50:525-541.

Myers, J. S. 1993. Precambrian history of the West Australian craton and adjacent orogens. Annu. Rev. Earth Planet. Sci. 21:453-485.

Myers, J. S.; Shaw, R. D.; and Tyler, I. M. 1996. Tectonic evolution of Proterozoic Australia. Tectonics 15: 1431-1446.

Nelson, D. R.; Myers, J. S.; and Nutman, A. P. 1995. Chronology and evolution of the middle Proterozoic Albany-Fraser Orogen, Western Australia. Aust. J. Earth Sci. 42:481-495.

Occhipinti, S. A.; Sheppard, S.; Passchier, C.; Tyler, I. M.; and Nelson, D. R. 2004. Palaeoproterozoic crustal accretion and collision in the southern Capricorn Orogen: the Glenburgh Orogeny. Precambrian Res. 128: 237-255.

Öhlander, B.; Mellqvist, C.; and Skiöld, T. 1999. Sm-Nd isotope evidence of a collisional event in the Precambrian of northern Sweden. Precambrian Res. 93:105117.

Oliver, N. H. S.; Holcombe, R. J.; Hill, E. J.; and Pearson, P. J. 1991. Tectono-metamorphic evolution of the Mary Kathleen fold belt, Northwest Queensland: a reflection of mantle plume processes? Aust. J. Earth Sci. 38:425-455.

Page, R.; Stevens, B. P. J.; Conor, C.; Preiss, W. V.; Crooks, A.; Robertson, S.; Gibson, G. M.; and Foudoulis, C. 2003. SHRIMP U-Pb geochronology in the Curnamona Province; improving the framework for mineral exploration. In Peljo, M., ed. Broken Hill Exploration Initiative: abstracts from the July 2003 conference. Canberra, Geoscience Australia, p. 122-125.

Page, R. W., and Laing, W. P. 1992. Felsic metavolcanic rocks related to the Broken Hill $\mathrm{Pb}-\mathrm{Zn}-\mathrm{Ag}$ orebody, Australia; geology, depositional age, and timing of 
high-grade metamorphism. Econ. Geol. Bull. Soc. Econ. Geol. 87:2138-2168.

Page, R. W.; Stevens, B. P. J.; Gibson, G. M.; and Conor, C. H. H. 2000. Geochronology of Willyama Supergroup rocks between Olary and Broken Hill, and comparison to northern Australia. In Peljo, M., ed. Broken Hill Exploration Initiative: abstracts of papers. Aust. Geol. Surv. Org. Rec. 10:72-75.

Page, R. W., and Sun, S.-S. 1998. Aspects of the geochronology and crustal evolution in the Eastern Fold Belt, Mt. Isa Inlier. Aust. J. Earth Sci. 45:343-361.

Park, A. F. 1985. Accretion tectonism in the Proterozoic Svecokarelides of the Baltic Shield. Geology 13:725729.

Patchett, P. J., and Arndt, N. T. 1986. Nd isotopes and tectonics of 1.9-1.7 Ga crustal genesis. Earth Planet. Sci. Lett. 78:329-338.

Patchett, P. J., and Chase, C. G. 2002. Role of transform continental margins in major crustal growth episodes. Geology 30:39-42.

Pearce, J. A.; Harris, N. W.; and Tindle, A. G. 1984. Trace element discrimination diagrams for the tectonic interpretation of granitic rocks. J. Petrol. 25:956-983.

Peccerillo, R., and Taylor, S. R. 1976. Geochemistry of Eocene calc-alkaline volcanic rocks from the Kastamonu area, northern Turkey. Contrib. Mineral. Petrol. 58:63-81.

Perini, G.; Francalanci, L.; Davidson, J.; and Conticelli, S. 2004. Evolution and genesis of magmas from Vico volcano, central Italy: multiple differentiation pathways and variable parental magmas. J. Petrol. 45:139182.

Pidgeon, R. T. 1990. Timing of plutonism in the Proterozoic Albany Mobile Belt, southwestern Australia. Precambrian Res. 47:157-167.

Roberts, M. P.; Pin, C.; Clemens, J. D.; and Paquette, J.L. 2000. Petrogenesis of mafic to felsic plutonic rock associations: the calc-alkaline Quérigut Complex, French Pyrenees. J. Petrol. 41:809-844.

Rubatto, D.; Williams, I. S.; and Buick, I. S. 2001. Zircon and monazite response to prograde metamorphism in the Reynolds Range, central Australia. Contrib. Mineral. Petrol. 140:458-468.

Rutland, R. W. R. 1973. Tectonic evolution of the continental crust of Australia: implications of continental drift to the earth sciences. Vol. 2, pt. 10. Continental evolution. London, Academic Press, p. 1011-1033.

Schaefer, B. F. 1998. Insights into Proterozoic tectonics from the southern Eyre Peninsula, South Australia. Ph.D. dissertation, University of Adelaide.

Scott, D. L.; Rawlings, D. J.; Page, R. W.; Tarlowski, C. Z.; Idnurm, M.; Jackson, M. J.; and Southgate, P. N. 2000. Basement framework and geodynamic evolution of the Palaeoproterozoic superbasins of north-central Australia: an integrated review of geochemical, geochronological and geophysical data. Aust. J. Earth Sci. 47:341-380.

Scrimgeour, I. R., and Close, D. F. 1999. Regional highpressure metamorphism during intracratonic defor- mation: the Petermann Orogeny, central Australia. J. Metamorph. Geol. 17:557-572.

Scrimgeour, I. R.; Close, D. F.; and Edgoose, C. J. 1999. Petermann Ranges, N. T. Northern Territory Geological Survey sheet SG52-7 explanatory notes. Darwin, Northern Territory Geol. Surv., scale $1: 250,000$.

Sen, C., and Dunn, T. 1994. Dehydration melting of basaltic composition amphibolite at 1.5 to $2.0 \mathrm{GPa}$ : implications for the origin of adakites. Contrib. Mineral. Petrol. 117:394-409.

Şener, A. K.; Young, C.; Groves, D. I.; Krapež, B.; and Fletcher, I. R. 2005. Major orogenic gold episode associated with Cordilleran-style tectonics related to the assembly of Paleoproterozoic Australia? Geology 33:225-228.

Sheppard, S.; Occhipinti, S. A.; and Tyler, I. M. 2004. A 2005-1970 Ma Andean-type batholith in the southern Gascoyne Complex, Western Australia. Precambrian Res. 128:257-277.

Sheppard, S.; Tyler, I. M.; Griffin, T. J.; and Taylor, W. R. 1999. Palaeoproterozoic subduction-related and passive margin basalts in the Halls Creek Orogen, northwest Australia. Aust. J. Earth Sci. 46:679-690.

Snyder, D. B.; Lucas, S. B.; and McBride, J. H. 1996. Crustal and mantle reflectors from Palaeoproterozoic orogens and their relation to arc-continent collisions. In Brewer, T. S., ed. Precambrian crustal evolution in the North Atlantic region. Geol. Soc. Spec. Publ. 112. London, Geol. Soc. Lond., p. 1-23.

Steltenpohl, M.; Hames, W.; Andresen, A.; and Markl, G. 2003. New Caledonian eclogite province in Norway and potential Laurentian (Taconic) and Baltic links. Geology 31:985-988.

Stewart, K. P. 1992. High temperature felsic volcanism and the role of mantle magmas in Proterozoic crustal growth: the Gawler Range Volcanic Province. Ph.D. dissertation, University of Adelaide.

Sun, S.-S., and McDonough, W. F. 1989. Chemical and isotopic systematics of oceanic basalts; implications for mantle composition and processes. In Saunders, A. D., and Norry, M. J., eds. Magmatism in the ocean basins. Geol. Soc. Spec. Publ. 42. London, Geol. Soc. Lond., p. 313-345.

Sun, S.-S., and Sheraton, J. 1992. Zircon U/ Pb chronology, tectono-thermal and crust-forming events in the Tomkinson Ranges, Musgrave Block, central Australia. AGSO Res. Newsl. 17:9-11.

Sun, S.-S.; Sheraton, J. W.; Glikson, A. Y.; and Stewart, A. J. 1996. A major magmatic event during 1050-1080 in central Australia and an emplacement age for the Giles Complex. AGSO Res. Newsl. 24:13-15.

Sun, S.-S.; Warren, R. G.; and Shaw, R. D. 1995. Nd isotope study of granites from the Arunta Inlier, central Australia: constraints on geological models and limitation of the method. Precambrian Res. 71:301-314.

Taylor, S. R., and McLennan, S. M. 1985. The continental crust: its composition and evolution. Oxford, Blackwell.

Teasdale, J. P. 1997. Methods for understanding poorly exposed terranes: the interpretive geology and tec- 
tonothermal evolution of the western Gawler Craton. Ph.D. dissertation, University of Adelaide.

Torsvik, T. H.; Smethurst, M. A.; Meert, J. G.; Van der Voo, R.; McKerrow, W. S.; Brasier, M. D.; Sturt, B. A.; and Walderhaug, H. J. 1996. Continental break-up and collision in the Neoproterozoic and Palaeozoic; a tale of Baltica and Laurentia. Earth-Sci. Rev. 40:229-258.

Turner, S.; Foden, J.; Sandiford, M.; and Bruce, D. 1993. Sm-Nd isotopic evidence for the provenance of sediments from the Adelaide Fold Belt and southeastern Australia with implications for episodic crustal addition. Geochim. Cosmochim. Acta 57:1837-1856.

Tyler, I. M. 2005. Australia: Proterozoic. In Selley, R. C.; Cocks, L. R. M.; and Plimer. I. R., eds. Encyclopedia of geology. Vol. 1. Oxford, Elsevier, p. 208-222.

Walter, M. R.; Veevers, J. J.; Calver, C. R.; and Grey, K. 1995. Neoproterozoic stratigraphy of the Centralian Superbasin, Australia. Precambrian Res. 73:173-195.

Whalen, J. B.; Syme, E. C.; and Stern, R. A. 1999. Geochemical and $\mathrm{Nd}$ isotopic evolution of Palaeoproterozoic arc-type granitoid magmatism in the Flin Flon Belt, Trans-Hudson orogen, Canada. Can. J. Earth Sci. 36:227-250.

White, R. W.; Clarke, G. L.; and Nelson, D. R. 1999. SHRIMP U-Pb zircon dating of Grenville-age events in the western part of the Musgrave Block, central Australia. J. Metamorph. Geol. 17:465-481.

Williams, I. S.; Buick, I. S.; and Cartwright, I. 1996. An extended episode of early Mesoproterozoic metamorphic fluid flow in the Reynolds Range, central Australia. J. Metamorph. Geol. 14:29-47.

Wingate, M. T. D.; Pirajno, F.; and Morris, P. A. 2004. Warakurna large igneous province; a new Mesoproterozoic large igneous province in west-central Australia. Geology 32:105-108.

Wyborn, D. 1992. Stratigraphy and geochemistry of Ordovician volcanics from the Lachlan fold belt in central New South Wales. In Webby, B. D., and Laurie, J.
R., eds. Global perspectives on Ordovician geology. Rotterdam, Balkema, p. 495-497.

Wyborn, L. A. I.; Page, R. W.; and McCulloch, M. T. 1988. Petrology, geochronology and isotope geochemistry of the post-1820 Ma granites of the Mount Isa Inlier: mechanisms for the generation of Proterozoic anorogenic granites. Precambrian Res. 40/41:509-541.

Young, D. N.; Duncan, N.; Camacho, A.; Ferenczi, P. A.; and Madigan, T. L. A. 2002. Ayers Rock, N. T. Northern Territory Geological Survey sheet SG52-8 explanatory notes. Darwin, Northern Territory Geol. Surv., scale $1: 250,000$.

Young, D. N.; Fanning, C. M.; Shaw, R. D.; Edgoose, C. J.; Blake, D. H.; Page, R. W.; and Camacho, A. 1995. $\mathrm{U}-\mathrm{Pb}$ zircon dating of tectonomagmatic events in the northern Arunta Inlier, central Australia. Precambrian Res. 71:45-68.

Zhao, J.-X. 1992. Proterozoic crust-mantle evolution in central Australia: geochemical and isotopic constraints. Ph.D. dissertation, University of Adelaide.

1994. Geochemical and Sm-Nd isotopic study of amphibolites in the southern Arunta Inlier, central Australia: evidence for subduction at a Proterozoic continental margin. Precambrian Res. 65:71-94.

Zhao, J.-X., and McCulloch, M. T. 1993. Melting of a subduction-modified continental lithospheric mantle; evidence from late Proterozoic mafic dike swarms in central Australia. Geology 21:463-466.

. 1995. Geochemical and $\mathrm{Nd}$ isotopic systematics of granites from the Arunta Inlier, central Australia: implications for Proterozoic crustal evolution. Precambrian Res. 71:265-299.

Zhao, J.-X.; McCulloch, M. T.; and Korsch, R. J. 1994. Characterisation of a plume-related approximately $800 \mathrm{Ma}$ magmatic event and its implications for basin formation in central-southern Australia. Earth Planet. Sci. Lett. 121:349-367. 
Copyright of Journal of Geology is the property of University of Chicago Press. The copyright in an individual article may be maintained by the author in certain cases. Content may not be copied or emailed to multiple sites or posted to a listserv without the copyright holder's express written permission. However, users may print, download, or email articles for individual use. 